\title{
LAW, RIGHTS, AND OTHER TOTEMIC ILLUSIONS: LEGAL LIBERALISM AND FREUD'S THEORY OF THE RULE OF LAW
}

\author{
ROBIN WEST ${ }^{\dagger}$
}

In the last ten years, a distinctively American jurisprudence has emerged as the dominant liberal theory of law. ${ }^{1}$ The proponents of this new theory have distinguished it from English legal positivism, ${ }^{2}$ the old "ruling" liberal theory, by taking seriously what the old theory purportedly denied: the autonomous and imperative role of moral rights and principles in legal discourse. Given their serious regard for rights and principles, it is no surprise that the new liberal theorists reject the two definitive claims of legal positivism-that law is the outcome of a positive political procedure and that there exists no necessary connection between law and morality ${ }^{3}$ - and endorse instead the natural lawyer's claim that law is both autonomous from politics and essential to the moral progress of civilization." These new liberal theo-

$\dagger$ Visiting Assistant Professor of Law, Stanford University. B.A. 1976, University of Maryland, Baltimore; J.D. 1979, University of Maryland; J.S.M. 1982, Stanford University.

1 Ronald Dworkin presented a version of this new theory in his 1978 book, Taking Rights Seriously. Dworkin contrasted his theory with legal positivism, which he characterized as the "ruling theory of law." R. DwORKIN, TAkING RIGHTS SERIousLy at vii (1978). English positivism is also widely purported to be a "liberal" theory of law. See id.

2 Dworkin is sharply critical of legal positivism, "which holds that the truth of legal propositions consists in facts about the rules that have been adopted by specific social institutions, and in nothing else." Id.

* The legal positivist insists that the morality of a norm is neither a sufficient nor a necessary condition of its legality. The legality of a norm is solely a function of social facts and carries with it no moral implications. See H.L.A. HART, THE CoNCEPT OF LAW 97, 181-82 (1961); see also R. DwORKIN, supra note 1, at vii, ix (citing Jeremy Bentham as the prototypical English positivist and H.L.A. Hart as English positivism's most important contemporary proponent).

4 The belief of the new liberal legal theorist as described by Dworkin is closely akin to the faith of the constitutional believer as described by Corwin 50 years ago. Both the old constitutionalist and the new legal liberal believe that the highest, most authoritative source of law is non-positivist and that obedience to that anti-historical, impersonal imperative "moralizes," as well as legalizes, power:

The theory of law thus invoked ... [predicates] certain principles of right and justice which are entitled to prevail of their own intrinsic excellence, altogether regardless of the attitude of those who wield the physical resources of the community. Such principles were made by no human hands; indeed, if they did not antedate deity itself, they still so express its nature as to bind and control it. They are external to all Will as such 
rists-including Owen Fiss, ${ }^{5}$ Laurence Tribe, ${ }^{6}$ Charles Fried, ${ }^{7}$ and Ronald Dworkin —regard the Rule of Law as the key to moral governance and civilized progress. I will call their theory of law "legal liberalism," and I will refer to the belief in law's necessary morality and autonomy from politics as a belief in the "Rule of Law," or as a commitment to "Rule-of-Law virtues."

This Article contends that Sigmund Freud's understudied but provocative legal theory ${ }^{9}$ contains one possible defense of the controversial commitments of American legal liberalism to the autonomy and morality of the Rule of Law. I will show that Freud posited both a history of the idea of law that entails its autonomy from politics and a description of our human nature that necessitates a moral component to law. Freud's history of the idea of law and his description of our human nature are consistent with the modern legal liberal's insistence on the autonomy of law from politics and on law's moral role in the history of civilization. Freud's account of law not only underscores liberal commitments, but also rebuts powerfully the criticisms of legal liberalism offered by today's leading non-liberal legal theorists.

I will call Freud's jurisprudential method "naturalistic," because

and interpenetrate all Reason as such. They are eternal and immutable. In relation to such principles, human laws are, when entitled to obedience save as to matters indifferent, merely a record or transcript, and their enactment an act not of will or power but one of discovery and declaration. . . .

Thus the legality of the Constitution, its supremacy, and its claim to be worshipped, alike find common standing ground on the belief in a law superior to the will of human governors.

Corwin, The "Higher Law" Background of American Constitutional Law, 42 HARv. L. REv. 149, 152-53 (1928) (footnote omitted).

See Fiss, Objectivity and Interpretation, 34 STAN. L. Rev. 739, 753 (1982).

- See Tribe, Constitutional Calculus: Equal Justice or Economic Efficiency?, 98 HaRv. L. Rev. 592 (1985).

7 See C. Fried, Contract as Promise (1981); C. Fried, Right and Wrong (1978).

${ }^{8}$ See R. Dworkin, supra note 1.

- See, e.g., S. Freud, Why War?, in Character and Culture (P. Rieff ed. 1963) [hereinafter S. Freud, Why War?]; S. Freud, Givilization and Its DisconTENTS (J. Strachey trans. 1961) [hereinafter cited as S. Freud, Grvilization]; S. Freud, Group Psychology and the ANalysis of the Ego (J. Strachey trans. 1959) [hereinafter cited as S. Freud, Group Psychology]. For an introduction to Freud's political theory, see P. RIEFF, Freud: The Mind of the Moralist (3d ed. 1979); P. Roazen, Freud: Political and Social Thought (1968). Although the political theory that Freud produced has been recognized and criticized by political theorists, the distinctive legal theory that he proposed has been neither heralded nor acknowledged by modern legal theorists. The notable exception is, of course, Jerome Frank's application of Freudian psychoanalytic ideas in LAW AND THE MODERN Mind (1930). Frank did not, however, focus on Freud's theory of law; instead he used Freud's psychoanalytic framework to develop his own skeptical position. 
his arguments for the morality and autonomy of law depend upon prior claims about human nature and human history. Although supported by Freud's conclusions, modern legal liberals would undoubtedly find his method fallacious. Following Hume ${ }^{10}$ and Kant, ${ }^{11}$ modern legal liberals

10 See D. Hume, A Treatise of Human Nature (London 1740).

11 Kant argued that a study of the origin and content of our moral duty must be independent of a study of our human nature and history:

[I]t never occurs to the authors [of essays on popular morality] to ask whether the principles of morality are ... to be sought anywhere in knowledge of human nature (which we can derive only from experience). And if this is not the case, if the principles are completely a priori, free from everything empirical, and found exclusively in pure rational concepts and not at all in any other place, they never ask whether they should undertake this investigation as a separate inquiry, i.e., as pure practical philosophy or . . . a metaphysics of morals. . . .

But a completely isolated metaphysics of morals, mixed with no anthropology, no theology, no physics or hyperphysics, and even less with occult qualities .... is not only an indispensable substate of all theoretically sound and definite knowledge of duties; it is also a desideratum of the highest importance to the actual fulfillment of its precepts . . . .

.. . [A]ll moral concepts have their seat and origin entirely a priori in reason. . . . [T] hey cannot be abstracted from any empirical and hence merely contingent conditions. In the purity of their origin lies their worthiness to serve us as supreme practical principles, and to the extent that something empirical is added to them just this much is subtracted from their genuine influence and from the unqualified worth of actions. Furthermore, it is . . . of the utmost practical importance to derive the concepts and laws of morals from pure reason ... a and to determine the scope of this entire ... rational knowledge ... without making the principles depend upon the particular nature of human reason . . . . [A]ll morals, which need anthropology for their application to men, must be completely developed first as pure philosophy ... independently of anthropology ....

I. Kant, Foundations of the Metaphysics of Morals 26-28 (L. Beck trans. 1959). The principles of morals themselves, as well as their study, must rely on grounds that are prior to facts about human nature:

If one wishes, the pure philosophy of morals (metaphysics) can be distinguished from the applied (i.e., applied to human nature), just as pure mathematics and pure logic are distinguished from applied mathematics and applied logic. By this designation one is immediately reminded that moral principles are not founded on the peculiarities of human nature but must stand of themselves a priori, and that from such principles practical rules for every rational nature, and accordingly for man, must be derivable.

Id. at 26 n.1. And finally, the categorical imperative, the absolute law of moral duty, commands obedience without regard to contingent facts of nature or history:

[I]t is extremely important to remember that we must not let ourselves think that the reality of this principle can be derived from the particular constitution of human nature. For duty is practical unconditional necessity of action; it must, therefore, hold for all rational beings (to which alone an imperative can apply), and only for that reason can it be a law for all human wills. Whatever is derived from the particular natural situation of man as such, or from certain feelings and propensities, or even from a 
insist on an unbridgeable divide between statements of fact regarding our particular history and contingent nature and normative claims regarding the universal content and categorical scope of our moral rights and obligations. ${ }^{12}$ Our moral obligations, including the distinctive moral obligation affirmed by legal liberalism-to obey the law-can therefore in no way depend upon any specified description of our human nature. As a result of this methodological commitment, legal liberal arguments for the morality and autonomy of law rest not on any particular description of our personality, but instead on intuitively grasped and noncontingent moral truths. I will argue that by the strength of example, Freud's jurisprudence suggests that the extreme antinaturalism of modern legal liberalism may be ill advised. The coherence of Freud's argument suggests the wisdom of grounding a jurisprudential defense of Rule-of-Law virtues in claims about essential human nature, rather than in appeals to our intuitive sense of right and wrong.

The Article has three parts. Part I outlines Freud's legal theory,

particular tendency of the human reason which might not hold necessarily for the will of every rational being . . . can give a maxim valid for us but not a law....

Id. at 43. For a general critique of Kant's radical separation of morals, the foundation of morals, and the study of morals from the contingent facts of our history, psychology, and anthropology, see A. MCINTYRE, AFTER VIRTUE 42-45 (1981).

12 See, e.g., B. Ackerman, Social Justice IN THE Liberal State 367-68 (1980) (both endorsing Kant's articulation of the good of autonomy and distinguishing it as being foundational, because noncontingent, from Ackerman's own commitment to autonomy); R. Dworkin, A MATTER OF PRINCIPLE 191 (1985) (arguing that the meaning of equality is "central to political theory at least since Kant"); R. DwORKIN, supra note 1, at 198 (asserting that holding that rights are prior to contingent, historical goals assumes either a Kantian respect for the dignity of the individual or "the more familiar idea of political equality"); C. FRIED, RIGHT AND WRONG 33, 197-98 (1978) (insisting on the priority of the absolute right over the contingent good derived from Kant).

All three writers insist that, despite Kant's claim to the contrary, morals must be grounded in some minimal description of the human personality. Their descriptions of the human personality, however, are as minimal, universal, and transcendent of history, anthropology, and psychology as Kant's own implicit, if not explicit, account of our nature. Thus, Charles Fried finds the foundation of morals in the individual's capacity for rational judgment and in the self's habitation of a physical body. See id. at 27-36. Fried concedes that his "absolute" categorical rights and wrongs are to that extent more contingent than Kant's, although it is highly unlikely that Kant would have disagreed with this limited specification of the physical conditions of moral truth. See id. at 33. With that exception, however, Fried's moral rights and wrongs are as categorical, universal, absolute, and free of both natural and historical contingency as Kant's. See id. at 9-17. Similarly, both Dworkin and Ackerman find the priority of autonomy and respect for the autonomy of others, which they consider central to liberal ethics, in our inability to generate contingent truths about the concrete, historical "good." See B. AckERMAN, supra, at 359-78; R. DwORKIN, supra, at 191-98 (arguing that liberalism requires governmental neutrality on the nature of the good and the content of the good life). 
including his speculative history of the origin of law and his description of our legal personality. Part II argues that Freud's history of the idea of law justifies legal liberalism's insistence on the autonomy of law from politics, while Freud's account of our legal personality explains the liberal doctrine that we are morally obligated to obey the Rule of Law. Part III explores Freud's theory of law further by setting forth his likely responses to three modern critics of legal liberalism and then contrasting those responses with arguments offered by legal liberals themselves. I hope to achieve two goals by thrusting Freud into modern debates. First, I hope to show that Freud's replies to the critics of legal liberalism underscore the persuasiveness of the Freudian defense of modern liberalism's substantive vision. Second, I hope to show that Freud's naturalistic method of defending the autonomy and morality of law is superior to the intuitionistic method of argument employed by the modern liberal theorists. The contrast between Freudian and liberal methods of defending the Rule of Law against critical attack lays the groundwork for a Freudian critique of legal liberal methodology.

The concluding section speculates on the future of legal liberalism's intuitionistic faith in the moral promise of law. In The Future of an Illusion, ${ }^{13}$ Freud concedes that while a naturalistic understanding of the history and function of religion renders religious faith more intelligible to the outsider, that same understanding explodes religion's claim to transcendental authority, and hence leads to its demise. A parallel argument can be applied to the legal liberal's faith in law. Although the history of the Rule of Law and an understanding of how obedience is mandated by our nature render the legal liberal's faith more intelligible, that very understanding undermines the law's claim of autonomy and transcendental moral authority, and thus weakens rather than strengthens its claim to our obedience. If this is true, then Freud's methodological naturalism cannot possibly be invoked as support for legal liberalism's transcendental commitments.

As Freud recognized, however, the analogy between. religion and law is a false one. ${ }^{14}$ Naturalistic analysis of the functional and histori-

1s S. Freud, The Future of AN Illusion (J. Strachey trans. 1961).

14 Although Freud provides essentially the same narrative as the basis of both religion and the Rule of Law, the prescriptive consequences he predicted for each differ dramatically. Freud clearly believed that civilization would gain by ridding itself of delusional, religious fantasies, but he predicted no such consequences with respect to the Rule of Law itself. On the contrary, he assessed the tradeoff between the freedom that the individual enjoyed in the natural hierarchy of the state of nature and the suppression endured in the artificial equality of civil society as an overall gain in individual happiness. Compare S. Freud, supra note 13, at 34-56 (positive social, moral, and rational gains to follow from the abandonment of religious faith) with S. FreUD, CrvILIZATION, supra note 9, at 41-45 (sacrifice of individual instinct to the Rule of Law 
cal bases of law may indeed strip law of its categorical and transcendental authority, but by doing so, it strengthens, not weakens, law's contingent and rational authority. This tradeoff entails a risk: empirical claims that strengthen the coherence while granting the contingency of the morality of law can be falsified as well as verified. The risk of not undertaking the inquiry, however, is far greater. Unless the legal liberals' claims are rendered amenable to naturalistic investigation, their faith in the morality of law will eventually be forgotten. Therefore, even if the particular naturalistic claims that justify faith in law are ultimately rejected, legal liberalism stands to gain by being rendered falsifiable, even if its premises are ultimately found to be false.

\section{Freud's Theory of the Rule of LAW}

In the last decade of his life, Freud turned his attention away from psychoanalysis to what he often claimed to be his original interest: social and political theory. ${ }^{15}$ The legal theory that Freud developed during these years was, like his better-known political theory, based on two fundamental claims about human nature: (1) the uninhibited individual possesses not just selfish, but dangerously antisocial instinctual desires that are constantly at war with civilization, ${ }^{16}$ and (2) the threat to civilization posed by these aggressive, antisocial desires is not and cannot be neutralized by the individual's capacity for empathy, communitarian altruism, nurturance, or, more simply, love. ${ }^{17}$ Together, these two fundamental elements of human nature create a "problem of power." How is it, given the individual's antisocial, aggressive desires, that the powerful-whether legislators, judges, majorities, "the American People," the "state," or private contractors-are ever capable of moral action? How is civilization possible, if the individual is instinctively hostile towards it?

Freud's legal theory consists of his historical and functional answers to these questions. The first section of Part I examines Freud's historical account of the origin of law. According to Freud, the creation of the Rule of Law was the historical solution to the problem of power. Freud first developed his historical explanation in Totem and Taboo ${ }^{19}$

heralded as the logical and desirable outcome of the development of civilization).

16 See P. RoAzEN, supra note 9, at 101-02, 107-08.

${ }^{16}$ See infra text accompanying notes 48-65; see also S. Freud, supra note 13, at 6 (describing "every individual [as] virtually an enemy of civilization"); id. at 7 ("[T]here are present in all men, destructive and therefore anti-social and anticultural, trends .....").

17 See infra text accompanying notes 51-65.

18 See infra text accompanying notes 48-50.

19 See S. Freud, Totem AND TABOo 182-87 (A. Brill trans. 1918). 
as an explanation of the origins not of law, but of totemism. Later, he used the same history in The Future of an Illusion ${ }^{20}$ to explain the operation of religion. Finally, in Civilization and Its Discontents Freud applied his historical account to the origin of law and public morality. The second section of Part I examines the functional role played by the Rule of Law in building civilization and combating the problem of power. Our need to obey impersonal, imperative norms, Freud argues, is the functional basis of civilization. We solve the problem of power arising from our antisocial desires by renouncing our individual, aggressive instincts. We achieve this renunciation by obeying the autonomous and objective mandates of the Rule of Law.

\section{A. The Origin of the Rule of Law}

In Totem and Taboo, Freud describes his vision of pre-civilized, pre-legal life, in which nomadic families, led and cared for by powerful and instinctually uninhibited fathers, lived communally. In this "father horde" the father exercised absolute power and maintained exclusive sexual possession of the horde's females. As his sons matured, their own developing desires for sexual fulfillment and power eventually threatened the father's absolute dominion. When the sons began to express their instinctual desires, the father's aggressive and sexual instincts overcame his inclination to nurture, and he ordered his sons to either renounce their instinctual cravings or be expelled from the horde. ${ }^{22}$ At some point the brothers of the father horde learned that they possessed a third option to the Hobson's choice of suppression or expulsion. By banding together cooperatively, they achieved what none could accomplish individually: they overpowered and killed the father. ${ }^{23}$

After the killing, however, the brothers unexpectedly experienced an overpowering feeling of remorse. As soon as the father was no longer a threat, the brothers' love, appreciation, and gratitude for the protection that he provided when they were children rose to the surface

${ }^{20}$ See S. Freud, supra note 13, at 22-24. Although Freud attributes the development of law and religion to the same historical event, he considers religion an unnecessary illusion antithetical to happiness and progress, see S. Freud, Givilization, supra note 9, at 31-32, while characterizing law as inevitable and necessary. See id. at 42.

21 See S. Freud, Crvilization, supra note 9, at 47-48.

22 See S. Freud, supra note 19, at 185 . Freud's conclusions were inspired by Darwin's speculations about primitive human society, which were based on his observations of ape behavior. See id. at 162-63.

${ }^{23}$ See id. at 183. Freud notes that the portion of this history dealing with patricide was also accepted by the anthropologist J.J. Atkinson in his book Primal Law (1903). See S. FREUd, supra note 19, at 183 n.78. 
of their consciousness. Liberation from the father's despotism enabled the sons to release their forgotten tenderness toward him. In response to their feelings of remorse, the sons constructed a substitute father, or totem, and pledged their "subsequent obedience"24 to its commands. By attributing to the substitute father the same commands that they had disobeyed in their act of rebellion, the brothers hoped to achieve a reconciliation with their dead father. "Ts "They undid their deed by declaring that the killing of the father substitute, the totem, was not allowed, and renounced the fruits of their deed by denying themselves the liberated women."26 Because the reconstitution was grounded in remorse for their deed, the first "command" attributed to the totem was the command not to do that which the brothers had just done-not to kill the totem animal, ${ }^{27}$ the substitute father.

Eventually, Freud continues, the brothers, through the totemic reconstitution of the father, extended the prohibition against killing the totem animal to all the brothers in the "brother horde," of Law was born. The resulting prohibition against murder neutralized the destabilizing consequences of the brothers' natural inequality. By obeying the command not to kill, each brother renounced his opportunity to replace the slain father, and the brothers lived in a state of artificial equality. The murder taboo thus facilitated social living. It is important to note, however, that the Rule of Law was not instituted as a matter of economic necessity, but originated from the emotional remorse following the original crime of patricide. ${ }^{2 \theta}$

24 "Subsequent obedience" is Freud's term for the sons' rechanneling of their obedience from the father to the father substitute (the totem) subsequent to the ultimate act of disobedience-the murder of the father. See S. FREUD, supra note 19, at 185.

${ }^{25}$ See id. at 186-87.

28 Id. at $184-85$.

27 Typically, the totem took the form of an animal that was accorded special respect by the community:
A strong animal, which perhaps at first was also dreaded, was found as a substitute. . . . The relationship to the totem animal retained the original ambivalency of feeling towards the father. The totem was, on the one hand, the corporeal ancestor and protecting spirit of the clan; he was to be revered and protected. On the other hand, a festival was instituted on which day the same fate was meted out to him as the primeval father had encountered. He was killed and eaten by all the brothers together . . . . This great day [the totem feast] was in reality a feast of triumph to cele- brate the victory of the united sons over the father.

S. Freud, Moses AND Monotheism 104-05 (K. Jones trans. 1939).

${ }_{28}$ S. FREUD, supra note 19 , at 189 . Freud goes on to note that "[i]t will still be a long time before the commandment discards the restrictions to members of the tribe and assumes the simple phraseology: Thou shalt not kill." Id.

${ }^{29}$ The rationalistic manner in which the Freudian brothers accepted society should not obscure the fact that guilt was their motive for embracing it. 
This history, Freud argues in The Future of an Illusion, helps to explain the discordance between "rational" and "moral" explanations of legal prohibitions. ${ }^{30}$ While it is possible to explain many legal prohibitions as rational responses to the insecurity created by a Hobbesian state of nature ${ }^{31}$-it is surely rational, for example, for a community to agree to reserve to itself the right to prohibit and punish murder ${ }^{32}$ - such rational explanations do not accord with the citizen's

It was an attempt to assuage the burning sense of guilt, and to bring about a kind of reconciliation with the father. The totemic system was a kind of agreement with the father in which the latter granted everything that the child's phantasy could expect from him ... in return for which the pledge was given ... not to repeat the act against the totem through which the real father had perished.

S. FREUD, supra note 19, at 186-87. In both motivation and historical vision, Freud's account of the patricidal brother horde differs from the better-known social contract theories.

Whereas Rousseau and Locke attempted to identify organized society's legitimacy, Freud simply sought the sources of social organization. Instead of the acts of voluntary consent and free will that Rousseau and Locke identified in the formation of society, Freud found "the expression of man's irrational longing for the return of authority." The Freudian collective was bound not by rational agreement, but criminal complicity. See S. FREUd, supra note 19, at 185. Furthermore, in Freud's community, the collective was still subject to the tyranny of the slain father. Traditional social contract theory found the triumph of the general will-the many over the one-in social and political organization, but Freud's totemic society was dominated by the will of the slain father. It was the father's resurrected supremacy to which the brother horde yielded. See id. at 185-86. Of course, at the same time, the fact that this filial obedience was subsequent to the father's death is a reminder that the many did successfully triumph over the one in the Freudian horde. See e.g., supra note 27 (describing the totem feast). Nevertheless, traditional social contract theory lacks both the concern with prior, external authority posited by Freud and the identification of guilt following the destruction of that authority as the motivation for the civilizing act. Compare J. RousseaU, ON THE Social ConTraCt 18-25 (D. Cress trans. 1983) and Barker, Introduction to J. Locke, AN Essay Concerning the Three Origins, Extent and END of Givil Government at xix-xxiv (1947) with S. FREUD, supra note 19, at 185-86.

so See S. FREUD, supra note 13, at 40-45.

s1 In the "state of nature" described by Hobbes, humans are passion-driven, untamed, and wantonly destructive. Existence in this state of nature is little more than a struggle for survival, a war of all against all. See T. HobBES, Leviathan 103 (new Am. ed. 1950) (1st ed. London 1651).

Hobbes does not claim that there was some historical period in which this state of nature described the condition of the entire human race. Rather, he uses it as a device to explore how a society would function without law. See id. at 105 ("I believe [the state of nature] was never generally so, over all the world . . . . Howsoever, it may be perceived what manner of life there would be, where there were no common Power to feare ....").

32 When civilization laid down the commandment that a man shall not kill the neighbour whom he hates ... . this was clearly done in the interest of man's communal existence, which would not otherwise be practicable. For the murderer would draw down on himself the vengeance of the murdered man's kinsmen and the secret envy of others, who within themselves feel as much inclined as he does for such acts of violence. . . . Insecurity of life, which is an equal danger for everyone, now unites men into a society 
sense that certain acts are punished because they are prohibited by something higher. Nor are such rational explanations likely to be effective. According to Freud, only an appeal to a higher moral authority will assure obedience, because "purely reasonable motives can effect little against passionate impulses." 33 What animates the public sense of justice is the conviction that the judge punishes what God prohibits, not what the community has agreed must be deterred. ${ }^{34}$ In secular, Blackstonian terms, the law prohibits not what ought rationally to be deterred or what is inefficient, but what is morally wrong. ${ }^{35}$ Hobbesian explanations of both the Rule of $\mathrm{Law}^{36}$ and of particular rules of law ${ }^{37}$ fail to account for the widespread intuition that law, to be legitimate, must be grounded in moral imperatives.

The rational account of the murder prohibition, ${ }^{38}$ Freud argued, accords with neither historical reality nor our moral sense. We experience the moral rule against killing, as well as the moral imperative that the legal official must punish killers, as imperatives issued from a higher authority because they were, originally, imperatives issued from a higher authority. The murder prohibition emanates from an authority separate from the brotherhood-the wishes and imperatives of the overthrown father. Indeed, the belief that this prohibition issues directly from God is accurate and fully justified, since "the primal father was the original image of God, the model on which later generations

which prohibits the individual from killing and reserves to itself the right to communal killing of anyone who violates the prohibition. Here, then, we have justice and punishment.

S. FReud, supra note 13 , at $40-41$.

3s Id. at 42:

Even in present-day man purely reasonable motives can effect little against passionate impulses. How much weaker then must they have been in the human animal of primaeval times! Perhaps his descendants would even now kill one another without inhibition, if it were not that among those murderous acts there was one-the killing of the primitive father-which evoked an irresistible emotional reaction with momentous consequences. From it arose the commandment: Thou shalt not kill.

st See id. at 40 .

ss See id. at $40-41$.

s6 Hobbes explained the need for the Rule of Law on the basis of self-interest. Hobbes observed that since "each man hath [Liberty] to use his own power . . . for the preservation of his own Nature," T. HoBBes, supra note 31, at 106, "there can be no security to any man" in the state of nature. Id. at 107. From this Hobbes derived the "Fundamentall Law of Nature": "to seek Peace, and follow it." Id.

s7 Particular rules of law imposed by the sovereign are justified in terms of the public good-as opposed to individual good, as with the Rule of Law-without appeal to morality. See id. at 298-99.

${ }^{38}$ See S. Freud, supra note 13, at 40 ("[W]e do not publish this rational explanation of the prohibition against murder. We assert that this prohibition has been issued by God."). 
have shaped the figure of God."39 Obedience to God's commands is our way of atoning for the original sin. ${ }^{40}$ The religious and moral explanation of the murder prohibition-that murder is prohibited because it is a violation of either divine or moral law-is thus closer to historical truth than is the rational explanation.

Like Hobbes, ${ }^{41}$ Freud employs a "state of nature" narrative in part to dramatize his view of our human nature. In this methodological respect, Freud's and Hobbes' state of nature parables are remarkably parallel. The substance of the tales, however, diverges sharply in three respects. First, in the Hobbesian state of nature, relatively equal ${ }^{42}$ and atomistic individuals war with each other in a state of each against all. ${ }^{43}$ Each person is equally vulnerable to the threat of death from the other, because it is relatively easy for any person, no matter how weak, to kill any other person, no matter how strong. We are all naturally equal, in Hobbes' view, because in a state of nature we are all equally vulnerable. ${ }^{44}$ The central social relationship is, therefore, horizontal: all are hostile towards all. The Freudian state of nature is not a state of natural equality. The Freudian natural state is one of natural inequality, in which the powerful both protect and exploit the weak, and the dependent both fear and need the strong. The central social relationship, then, is vertical: the Freudian natural state is one characterized by the centrality of relationships of personal authority dictated by unequal distributions of natural strength.

Second, the inhabitants of the Hobbesian natural world respond to

so Id. at 41-42.

10 In Freud's theological system, original sin refers to the murder of the primal father. See S. FREUD, supra note 19, at 198-99.

i1 See T. HobBEs, supra note 31 , at $69-78$. One commentator summarized the Hobbesian view of human nature this way: "Man is a complex of powers; desire is the desire for power, pride is illusion about power, honour opinion about power, life the unremitting exercise of power and death the absolute loss of power." M. OAKESHOTT, HobBes on Civil Association 18 (1975).

12 See T. HobBes, supra note 31, at 101:

Nature hath made men so equall, in the faculties of body, and mind; as that though there bee found one man sometimes manifestly stronger in body, or of quicker mind then [sic] another; yet when all is reckoned together, the difference between man, and man, is not so considerable, as that one man can thereupon claim to himselfe any benefit, to which another may not pretend, as well as he.

is See id. at 103-04; cf. S. Freud, Civilization, supra note 9, at 69 (using the Hobbesian phrase "each against all and all against each" in describing the way in which the aggressive instinct opposes the program of civilization).

44 See T. HoBBes, supra note 31 , at 101 . Hobbes does not maintain that all personalities are the same in their desire to increase their power. Rather, even those individuals who are relatively modest in their desires are forced to secure power to fend off the attacks of those who are more acquisitive in nature. See T. HoBbes, DE Crve 54 (S. Lamprecht ed. 1949). 
the instability of their state of natural equality and the murderous instability that it entails by creating a political authority of artificially unequal strength and power..$^{45}$ The inhabitants of the Freudian natural world, on the other hand, do just the reverse: they respond to their state of natural inequality by creating an unnatural equality-by revolting against the stronger, and then renouncing their individual aspirations to succeed him. The Freudian compact that enables transcendence of the state of nature is the destruction of oppressive natural authority based on superior strength, while the Hobbesian compact that enables transcendence from the state of nature is the construction of artificial authority based on superior strength. The Hobbesian state is the result of a pro-authoritarian act that has its genesis in a rational response to the danger of a natural world without personal authority. The Freudian state is the product of a revolutionary anti-authoritarian act of disobedience that has its genesis in the danger of a natural world governed by personal, exploitative, oppressive authority.

Finally, the Hobbesian state achieves equilibrium through the mechanism of shared fear, ${ }^{46}$ while the Freudian state achieves equilibrium through the mechanism of shared obedience to an impersonal, non-aggressive, protective rule of authority, reconstituted by the community itself. ${ }^{47}$ The Hobbesian state is empowered by the original contractors, but it operates from that point against them. The Freudian Rule of Law is also a creation of the original contractors, but it is continually reconstituted by those whom it protects. In the language of the liberal, the Rule of Law is ours: it embodies the community's victory over personal power. It rules by precluding, by virtue of its existence, the danger of personalized, aggressive power. The Hobbesian Leviathan, by contrast, is not ours, nor is it us. It rules by embodying the personalized aggressive power that the Freudian primal horde successfully overthrew. The Hobbesian compact, in short, yields a political authority, while the Freudian compact yields an autonomous Rule of Law.

\section{B. The Problem of Power}

Why are the powerful not inclined to use power in socially benefi-

45 This repository of unequal strength and power is the "LEviatHaN, or rather . . . [the] Mortal God, to which wee owe under the Immortal God, our peace and defence." T. HOBBEs, supra note 31, at 143.

48 To Hobbes, the Leviathan is "[t]he only way to erect such a Common Power, as may be able to defend them from . . . the injuries of one another, and thereby to secure them." Id. at 142-43.

${ }^{47}$ See S. FREUD, supra note 19, at 188-89. 
cial, moral ways? What threat does the individual's uninhibited desire pose to civilization? The uninhibited individual is innately aggressive, dangerously antisocial, and intent on the destruction of civilization:

[M]en are not gentle creatures who want to be loved, and who at the most can defend themselves if they are attacked; they are, on the contrary, creatures among whose instinctual endowments is to be reckoned a powerful share of aggressiveness. As a result, their neighbour is for them not only a potential helper or sexual object, but also someone who tempts them to satisfy their aggressiveness on him, to exploit his capacity for work without compensation, to use him sexually without his consent, to seize his possessions, to humiliate him, to cause him pain, to torture and to kill him. . . . In circumstances that are favourable to it, when the mental counter-forces which ordinarily inhibit it are out of action, [aggression] . . . manifests itself spontaneously and reveals man as a savage beast to whom consideration towards his own kind is something alien. ${ }^{48}$

This antisocial tendency towards aggression and destruction finds expression in the actions of anyone with unrestrained power. In Freud's primeval history of the father and the brother horde, the natural instinctual desires of both the weak and the strong are destructive of collective life. The strong father will nurture the weak sons only as long as they remain powerless. When the sons approach natural equality, the father becomes antisocial, murderous, aggressive, possessive, and jealous. The sons also harbor antisocial desires, but these desires are inhibited by the father's superior strength. When the weak are empowered through collective action, however, they explode in an act of antisocial patricide. Prior to the institution of the totem, the aggression of the brothers differed from that of their father only in its collective nature. In both cases power was used to destroy, rather than nurture, the social unit.

In the Freudian vision, the original act of patricide, by shifting the power base from the one to the many, ushered in the institution of law and legal rights. ${ }^{48}$ Although the work of civilization began with this collective action, to be complete it could not stop there; it had to go further and construct a permanent community committed to self-

48 S. Freud, Civilization, supra note 9, at 58-59.

19 See id. at 46-48. 
preservation.

$[\mathrm{T}]$ he power of those who were united now represented law in contrast to the violence of the single individual. . . . The only real difference lies in the fact that what prevails is no longer the violence of an individual but that of a community. But in order that the transition from violence to this new right or justice may be effected ... [ [t]he union of the majority must be a stable and lasting one. If it were only brought about for the purpose of combating a single domineering individual and were dissolved after his defeat, nothing would have been accomplished. . . . The community must be maintained permanently, must be organized, must draw up regulations to anticipate the risk of rebellion and must institute authorities to see that those regulations-the laws-are respected .... The recognition of a community of interests such as these leads to the growth of emotional ties between the members of a united group of people-feelings of unity which are the true source of its strength. ${ }^{50}$

The historically civilizing act was the creation of the Rule of Law, which in turn produced a state of artificial equality that facilitated the coming together of individuals into larger units. While the concerted power of the horde was enough to overcome the power of the single despot, the creation of an interdependent community was necessary to prevent the recurrence of destructive acts of violence by either individuals or groups. Givilization, which had been created in order to overcome the father's despotism, still required a means of ensuring its own continued existence.

One possible way to perpetuate civilized society is through the manipulation of eros, the love instinct. Eros is a creative, unifying impulse. $^{51}$ In its most basic form, eros is the libidinal instinct that drives the individual towards union with another. This instinct for creative union is replicated through increasingly larger groups of individuals: the family, the community, the nation, and finally all of civilization. Civilization itself has a libidinal drive that enables the creation of larger and larger associations among individuals. ${ }^{\mathbf{6 2}}$

so See S. Freud, Why War?, supra note 9, at 136-37.

s1 See id. at 141.

52 See S. FreUd, Grvilizatron, supra note 9, at 87 (In the process of civilization, "the most important thing is the aim of creating a unity out of the individual human beings."). 
Reliance on eros to prevent the disintegration of civilization, however, is problematic for two reasons. First, the individual's creative, civilizing, erotic drive towards unity will always be opposed by the equally powerful antisocial death instinct that lies beneath aggressive impulses. Whereas eros is creative and life-giving, the death instinct is the fundamental, indissoluble craving for the death of all living organisms, including the social organism of civilization: ${ }^{53}$ "[T]his instinct is at work in every living being and is striving to bring it to ruin and to reduce life to its original condition of inanimate matter. Thus it quite seriously deserves to be called a death instinct, while the erotic instincts represent the effort to live." ${ }^{\text {"S4 }}$ In the struggle between eros and the death instinct, neither combatant will ever win. In identifying the death instinct, Freud does not propose a cure; rather, he simply recognizes and describes an inescapable state of being. ${ }^{55}$ Because aggression is ineradicable, love can never solve the problem of power for civilization.

The second and more fundamental difficulty in civilization's attempt to solve the problem of power through the encouragement of love lies in the ambivalent attitude of eros itself toward civilization. While aggression works unambiguously against civilization, eros struggles against civilization at the same time that it fosters it. The individual's capacity for erotic love typically exhausts itself in the unity of pairs. This love, like aggression, is by nature antisocial; it is exclusive, possessive, and jealous. ${ }^{58}$ Thus, the libidinal inclination of civilization towards ever greater combinations of individuals is in fact at odds with the individual's narrower libidinal impulse:

[S]exual love is a relationship between two individuals in which a third can only be superfluous or disturbing, whereas civilization depends on relationships between a considerable number of individuals. When a love-relationship is at its height there is no room left for any interest in the environment; a pair of lovers are sufficient to themselves, and do not even need the child they have in common to make them happy. ${ }^{57}$

While the individual's erotic instinct may be satisfied by combination with just one other individual, the libidinal drive of civilization de-

s3 See id. at 58-59.

S. FREUD, Why War?, supra note 9, at 143.

sB See id. at 143-44. Freud also describes how the two impulses, eros and death, scarcely ever operate in isolation. They may act in concert or in opposition, but they always operate together. See id. at 141-42.

se See S. Freud, Civilization, supra note 9, at 55.

s7 Id. 
mands much larger combinations. Civilization must therefore manipulate, not simply utilize, the same instinct that unites the sexually connected couple to create nonsexual emotional ties among members of the community. Thus, "aim-inhibited affection"s8 - the emotion we feel toward family members, friends, and others in the society-is a diluted form of the fundamental erotic instinct.

The most basic form of social organization based on aim-inhibited affection is, of course, the family. The family is a hybrid of the one-onone exclusivity of fully sexual love and the expansive trend of civilization's libidinal goals. Several manifestations of the opposition between the libidinal directions of the individual and the community are apparent in the tensions among the individual, the family, and civilization. First, civilization's tendency toward larger social units opposes the individual's instinctual sexual hunger for incestuous objects, thereby denying that outlet within the context of the family. ${ }^{\text {"9 }}$ Second, the "work" of civilization and the "work" of love are in economic conflict. ${ }^{60}$ If the

s8 The love which founded the family continues to operate in civilization both in its original form, in which it does not renounce direct sexual satisfaction, and in its modified form as aim-inhibited affection. In each, it continues to carry on its function of binding together considerable numbers of people, and it does so in a more intensive fashion than can be effected through the interest of work in common. The careless way in which language uses the word 'love' has its genetic justification. People give the name 'love' to the relation between a man and a woman whose genital needs have led them to found a family; but they also give the name 'love' to the positive feelings between parents and children, and between the brothers and sisters of a family, although we are obliged to describe this as 'aim-inhibited love' or 'affection.' Love with an inhibited aim was in fact originally fully sensual love, and it is so still in man's unconscious. Both-fully sensual love and aim-inhibited love-extend outside the family and create new bonds with people who before were strangers. Genital love leads to the formation of new families, and aim-inhibited love to 'friendships' which become valuable from a cultural standpoint because they escape some of the limitations of genital love, as, for instance, its exclusiveness.

Id. at 49-50.

89 See id. at 51 .

60 The term "economic" is used elsewhere in this Article in its traditional sense, to mean wealth maximizing through expediency and mutual advantage. Here, I am using "economic" as Freud employs it, to refer to the quantitative aspect of psychoanalysis. See P. Roazen, supra note 9, at 69-70. Freud believed that the id is composed of quanta of energy derived from the instincts and that it is governed by the "economic" principle of the discharge of energy. See S. Freud, Beyond the Pleasure Principle 43 (J. Strachey trans. 1950) [hereinafter cited as S. Freud, Pleasure Principle]. Freud's "economic" principle is related to the pleasure principle, in that pleasure is produced by a lowering of psychical excitation. See id. at 1; S. Freud, A General INTRODUCTION TO PsYchoANALYSIS 364-65 (J. Riviere trans. 1963) [hereinafter cited as S. FreUd, GenERAL InTroduction]. Freud believed that psychological disorder was a result of the maldistribution of psychical energy. See P. RoAzen, supra note 9, at 70 . 
work required to sustain the growing community is to be carried out, libidinal energy must be taken from the family and the primary libidinal relationship and redirected toward societal tasks. ${ }^{61}$ Third, since the family is the product of the primary sexual instinct, it is hostile to civilization's endeavors to break it up. ${ }^{62}$

Freud's postulation of a fundamental incompatibility between the erotic drive of civilization and the individual's erotic instinct runs counter to the "ethical view" that posits universal love as the highest goal of civilized life. ${ }^{68}$ Freud insists that, because it is not a part of the individual's makeup, the capacity for public or brotherly love simply does not exist. ${ }^{64}$ Indeed, contrary to the utopian and Christian depiction of the nature of love, to Freud the commandments to love our neighbors and to love our enemies are both unreasonable and impossible to obey:

[One of the ideal demands of civilized society] runs: 'Thou shalt love thy neighbor as thyself.' . . . Why should we do it? What good will it do us? But, above all, how shall we achieve it? How can it be possible? My love is something valuable to me which I ought not to throw away without reflection. It imposes duties on me for whose fulfillment I must be ready to make sacrifices. If I love someone, he must deserve it in some way. . . . But if he is a stranger to me and if he cannot attract me by any worth of his own or any significance that he may already have acquired for my emotional life, it will be hard for me to love him. . . . [I]f I am

61 Freud expounds this thesis in a now notorious passage centered on the hostility of women toward civilization:

[W]omen soon come into opposition to civilization and display their retarding and restraining influence-those very women who, in the beginning, laid the foundations of civilization by the claims of their love. Women represent the interests of the family and of sexual life. The work of civilization has become increasingly the business of men, it confronts them with ever more difficult tasks and compels them to carry out instinctual sublimations of which women are little capable. Since a man does not have unlimited quantities of psychical energy at his disposal, he has to accomplish his tasks by making an expedient distribution of his libido. . . . Thus the woman finds herself forced into the background by the claims of civilization and she adopts a hostile attitude towards it.

S. Freud, Civilization, supra note 9, at 50-51.

62 [O]ne of the main endeavours of civilization is to bring people together into large unities. But the family will not give the individual up. The more closely the members of a family are attached to one another, the more often do they tend to cut themselves off from others, and the more difficult is it for them to enter into the wider circle of life.

Id. at 50 .

es See id. at 49.

64 See id. at 56-59. 
to love him (with this universal love) merely because he, too, is an inhabitant of this earth, ... then I fear that only a small modicum of my love will fall to his share . . . What is the point of a precept enunciated with so much solemnity if its fulfillment cannot be recommended as reasonable? ${ }^{65}$

Thus, although love-both instinctual and aim-inhibited-does do some of the work needed to perpetuate the community, Freud concludes that love is not sufficient. It is neither strong enough to restrain aggression nor free of its own ambivalence; eros has within itself antisocial, incestuous goals that imperil civilization's expansive program. Thus the erotic instinct alone cannot establish a larger, cooperative civilization; indeed, it militates against it. Protection for the communal unit must be found elsewhere.

Freud postulates that the instrument of established civilization is the institutionalization of guilt, the renunciation of desire having its roots in the installation of the totem by the brother horde. ${ }^{66}$ The reconstituted totemic entity did as the father had done-it commanded the brothers' renunciation of instinct. The brothers gave it what they had earlier refused to give their father-obedience. ${ }^{67}$ This "subsequent obedience" of the brothers to the totem was a covenant with a new, idealized "father," who would provide protection and care in exchange for the brothers' promise to forego the desires that brought about the destruction of the original father. ${ }^{68}$

Renunciation and obedience were born of the ambivalent feelings the sons felt toward their father before his death. The brothers hated the father for frustrating their instinctual desires, but they loved him for protecting them during their period of total dependence and vulnerability. ${ }^{69}$ As long as the need for protection was paramount, the sons renounced their aggressive and sexual feelings. When resentment became paramount, love was displaced by instinctual aggression. After the

6s Id. at 56-57 (footnote omitted). Freud concludes that

there is a second commandment, which seems to me even more incomprehensible and arouses still stronger opposition in me. It is 'Love thine enemies.' If I think it over, however, I see that I am wrong in treating it as a greater imposition. At bottom it is the same thing.

Id. at 57 .

${ }^{66}$ See id. at 79-80.

- See S. Freud, supra note 19, at 185.

${ }^{\text {BB }} \mathrm{Id}$. at 186.

a9 See S. Freud, supra note 13, at 30 (asserting that the attitude of the child toward the father, which forms the basis of the wish underlying religious sentiment, is derived from the child's helplessness and its resulting desire and need for paternal protection). 
father was killed, the brothers' anger and resentment was satisfied and only filial love remained. From the childhood love for the father issued the remorse that generated the renunciation and obedience on which civilization depends. ${ }^{70}$ Thus, the morality felt of the Rule of Law reflects not a rational agreement eventually struck between a community of equals, but rather the need for voluntary, renunciatory obedience to a protective and impersonal authority.

Although founded primarily on guilt, instinctual renunciation also had practical importance in postpatriarchal society. ${ }^{71}$ After the brothers rebelled against and killed the father, they were free of his aggression, but they were also in the same state of helplessness that they had occupied as children relying on the father's protection. ${ }^{72}$ The external world continued, to be a dangerous, hostile place, and more important, after the deed each brother's aggressive instinct posed a new threat to collective survival. Natural aggressiveness combined with inequality of strength rendered collective life unstable: the strongest would succeed to the position of the father, and the cycle would be repeated. Thus, the brothers experienced a novel, collective need for individual renunciation of aggressive desire. ${ }^{73}$

The renunciation and obedience of the brother horde established the system of values on which later totemic authorities, such as religion, law, and positive morality, would come to depend. ${ }^{74}$ That which is "bad" is that which deprives the individual of the protective agent's love. During their childhood, the brothers developed a functional definition of "good" and "bad" that was tied directly to their survival instinct. They experienced as bad all influences, whether external or internal, that threatened the flow of paternal protection. ${ }^{75}$ The aggressive urge toward the father and the sexual urge toward the mother were two such dangerous internal influences. Those instincts were considered bad because their very existence threatened that on which the sons relied-the father's protection. Each son resolved the dilemma by obeying the father's command to repress his instinctual cravings. He thereby retained the desired paternal protection, although at a considerable psychic cost. After the collapse of the father horde, the brothers applied the same strategy. They renounced the same instincts through the same mechanism of obedience to authority, fended off the danger posed by

70 See S. Freud, Civilization, supra note 9, at 79-80.

71 See supra note 29 and accompanying text.

72 See S. FreUd, supra note 13, at $30,42$.

7s See id. at 42.

74 See S. Freud, Givilization, supra note 9, at 71.

${ }^{75}$ See id. at 71-79. 
their instinctual aggression, and thereby assured themselves of the continued protection of collective living. The brothers' fear of the loss of paternal protection reasserted itself, was experienced as "remorse," and motivated obedient renunciation of instinctual desire and the creation of a totem that would command obedience. ${ }^{78}$

Modern civilization continues to demand renunciation and obedience to the Rule of Law. As civilization becomes more complex, it demands new sacrifices, so that "human culture is established through a series of renunciations."77 The continued existence of the Rule of Law, and hence of civilization, ultimately depends on the powerful individual's capacity for "subsequent obedience" to its mandates. That obedience, in turn, demands that the powerful individual tolerate the burden of guilt that the need for obedience implies, and the discontent that it engenders. Although the instinctual repressions demanded by civilization cause frustrations and unhappiness that are sometimes extreme, ${ }^{78}$ these repressions are essential to the existence of civilization and are thus the price that must be paid for continued security against aggression. On the value of civilization, Freud is, in the end, ambivalent. ${ }^{79}$ The discontent engendered by instinctual renunciation is the source of all neurosis. Nevertheless, the natural instinct of aggression cannot be bred out of humankind and so must be restricted and controlled. In choosing whether law or instinct should prevail, Freud therefore chooses law. ${ }^{80}$ Although repressive, because it is self-imposed the Rule of Law represents a significant advance beyond the obedience required in the father horde. The community implements the repressions of law in its own interest. We create the Rule of Law because it satisfies our

${ }^{26}$ See S. FreUd, supra note 13, at 42; S. FREUd, supra note 19, at 185-86.

77 P. RIEFF, supra note 9, at 197.

28 See S. Freud, Grvilization, supra note 9, at 86 ("When an instinctual trend undergoes repression, its libidinal elements are turned into [neurotic] symptoms, and its aggressive components into a sense of guilt."); see also S. FrEUD, GENERAL INTRODuCTION, supra note 60 , at 304-08, 442-47 (discussing how repression leads to manifest psychopathology and the usefulness of psychoanalysis in treating the condition by removing repression). On a collective level, Freud likens religion to a form of social neurosis, born out of the necessity for instinctual repression, the overthrow of which would help reconcile individuals to civilization. See S. FREUD, supra note 13, at 42-45.

70 See P. RoAzEN, supra note 9, at 256 ("Freud saw [the] Janus character of social life, the sense in which society both frustrates and fulfills men's needs. Depending on whether he is concentrating on the sexual or aggressive drives, he is more or less aware of the restrictive or the purposive aspects of social life."). Compare S. FREUD, Civil.zation, supra note 9, at 51-52 (asserting that the heterosexual, monogamous norm of our society is unduly repressive, unnecessary, and indifferent to differences among people) with S. FREUD, supra note 13, at 7 ("It seems rather that every civilization must be built upon coercion and renunciation of instinct . . . .") and id. at 8 (arguing that civilization depends on the renunciation of instinct).

Bo See S. Freud, Givilization, supra note 9, at 42. 
greatest need: to obey.

How is remorse kept alive through succeeding generations, after the initial act has been forgotten? Given Freud's world view, this is not problematic. First of all, Freud was a Lamarckian, ${ }^{81}$ and he believed generally in an "archaic heritage" or race memory and specifically that "[s]o important an experience [as] . . the primal crime . . . 'must have left some permanent trace in the human soul." "\$2 Second, Freud believed in phylogeneticism ${ }^{83}$ whereby-each individual passes through all the developmental stages of its forebears. Furthermore, none of these developmental stages ever ceases to exist; "the primitive mind," wrote Freud, "is, in the fullest meaning of the word, imperishable." there is tradition, which is passed from generation to generation through the agency of the superego ${ }^{85}$-the individual's source of totemic authority. Each individual inherits the contents of his parents' superego, so that the value system and laws of each generation are

81 See P. RIEFF, supra note 9, at 199. The Lamarckian hypothesis states that subsequent generations inherit the acquired characteristics of their forebears. See S. Mason, A History of THE Sciences 329 (rev. ed. 1962). This inheritance goes beyond simple animal instinct because it incorporates in memory the experiences of earlier generations.

${ }_{82}$ S. FREUD, supra note 27 , at 167.

Bs The theory of phylogeneticism followed by Freud holds "that the individual mind presents in its development a resume of [all] the stages of human history." $P$. RIEFF, supra note 9, at 188. Freud rejects the phylogenetic view as far as the physical development of the human body is concerned. See S. Freud, Civilization, supra note 9, at 18. Phylogeneticism's influence on Freud is evident in the psychoanalytic method and is most apparent in his association of children with primitives. Where the desire for the mother and the consequent murderous hatred and jealousy toward the father are the controlling passions of primitive life, the Oedipal complex is an inevitable stage of early childhood development, from which the child, like humanity at large, learns to recover. See id. at 78; see also P. RIEFF, supra note 9, at 189-90 (discussing Freud's analogies between children and primitives).

8414 S. Freud, The Standard Edition of the Complete Psychological Works of Sigmund Freud 286 (J. Strachey and A. Freud eds. 1979); see also id. at 285 ("[E]very earlier stage of development persists alongside the later stage which has arisen from it . . . "); $c f$. S. FreUd, Civilization, supra note 9, at 16-18 (likening the mind to a fanciful vision of the city of Rome, wherein all the buildings and monuments of its long history exist side by side).

${ }^{85}$ The "conscience" of the individual is a function of the superego. See S. Freud, Crvilization, supra note 9 , at 83 . The superego is to the individual what the totem is to primitive society and law is to modern society: the internalized source of objective authority that forces the suppression of instinct necessary for social life. See id. at 88-90 (describing a "cultural superego"). As the institution of totemic authority is the primitive response to the Oedipal conflict, the superego develops when the child learns to renounce his desires in order to retain parental love. Like the primitive brothers, the child replaces the restrictions of the parents with his own self-imposed restrictions. The superego represents the internalization of the parental restrictions in the child's mind. Civilization, according to Freud, "obtains mastery over the individual's . . . desire for aggression by weakening and disarming it and by setting up within him an agency to watch over it, like a garrison in a conquered city." Id. at 70-71. 
handed down to all members of society through their families:"86 "society acts through the family; in each individual family custom gets internalized into each new member of society." 87

\section{Freud's Defense of Legal Liberal Commitments}

\section{A. The Legal Liberal Rule of Law}

The distinctive claim of American legal liberalism is that the only moral solution to the problem of power is obedience to law. By "law," however, legal liberals do not mean the morally neutral, positive mandates of the politically empowered. Instead, the law that does and should command our obedience is both autonomous from the political process and rich in moral content. ${ }^{88}$ Law consists of an indeterminate number of binding moral rights and principles, none of which are attributable to any positive act of a political sovereign. ${ }^{89}$ In Dworkin's influential jurisprudence, moral "principles" are not posited by political actors, ${ }^{90}$ but somehow emerge from the community without ever being posited by it. ${ }^{91}$ Moral "rights" are similarly unposited, but unlike principles, emerge not from the community, but from individuals themselves. ${ }^{92}$ The insistence upon the existence, and even the source, of these moral rights and principles would be unremarkable were it not for the legal liberals' claim that these moral entities constitute the "law." However, it is precisely this problematic identification of these moral rights and principles with law that ensures both the law's morality and its autonomy from politics. ${ }^{9 s}$ To legal liberals, a society whose political structure lacks a recognition of the legal status of moral rights and

${ }^{88}$ The superego in the child is

constructed on the model not of its parents but of its parents' superego; the contents which fill it are the same and it becomes the vehicle of tradition and of all the time-resisting judgments of value which have propagated themselves in this manner from generation to generation. . . Mankind never lives entirely in the present. The past, the tradition of the race and of the people, lives on in the ideologies of the super-ego . . . .

S. Freud, New Introductory Lectures on Psychoanalysis 67 (J. Strachey trans. 1965).

87 P. ROAZEN, supra note 9, at 189.

88 See R. DwORkIN, supra note 1, at 14-39; Tribe, supra note 6, at 596.

so See R. DwORKIN, supra note 1 , at 44 .

90 See id. at 28 .

21 See id. at 41-79.

92 In Laurence Tribe's terms, moral "rights" are not positivistically "assigned" to the individual; instead, they inhere in the individual "organically and historically." See Tribe, supra note 6 , at 596.

ss See R. DWORKIN, supra note 1, at 14-39. 
principles in some important sense also lacks "law."94

Although they differ in form, origin, and content, these morally rich "laws"- whether rights, principles, or both-share four distinctive characteristics. First, and most fundamentally, legal rights and principles impose moral, not simply prudential, obligations. The Dworkinian judge is morally bound to enforce litigants' rights through the application of nonpositivistic principles, and the case decided in accordance with binding rights and principles is a moral adjudication. ${ }^{95}$ Constitutionally mandated authority, Owen Fiss argues, is moral authority. ${ }^{90}$ Otherwise diverse legal liberal theorists-Laurence Tribe, Owen Fiss, Ronald Dworkin, and Charles Fried-all agree that individual and minority rights morally, as well as authoritatively and imperatively, trump conflicting inclinations of both egotistic individuals and happiness-seeking communities. ${ }^{97}$ More abstractly, Charles Fried insists that the categorical imperative, central to legal liberalism's deontological account of both principle and right, is indeed a moral imperative-the moral duty to obey is an obligation we all share. ${ }^{88}$

Second, the moral principles and rights that constitute true law in the legal liberals' world are imperatives that secure compliance not through threats and sanctions, but through the conscientious obedience of the powerful. ${ }^{99}$ The judge, for example, is bound to enforce litigants' pre-existing rights in accordance with principle ${ }^{\mathbf{1 0 0}}$ not by the threat of a more powerful sovereign, but by her sense of moral obligation. Although the judge is a powerful political actor, she abdicates that power when she acts according to her sense of moral obligation. A judge who complies with the Rule of Law lacks, in Dworkin's language, the "discretion" to decide a case in any way but the correct one. ${ }^{101}$ Analogously, although majorities and communities are politically powerful, when they act according to the Rule of Law they abdicate that power and yield to the rights of disempowered minorities and individuals. The

of See id.

${ }^{95}$ See id. at 35.

${ }^{86}$ See Fiss, supra note 5, at 763 ("TT]he Constitution embodies a public morality[,] and . . . a public life founded on that morality can be rich and inspiring.").

${ }^{97}$ See R. DwORKIN, supra note 1, at 184-205; C. FRIED, supra note 12, at 16263; Fiss, supra note 5, at 763; Tribe, supra note 6, at 617-18.

${ }^{28}$ See C. FrIED, supra note 12, at 7-13. According to Fried, notions of "[absolute] right and [absolute] wrong are the foundations of our moral personality. . . . [These notions] establish our basic position as freely choosing entities. That is why nothing we choose can be more important than the ground-right and wrong-for our choosing." Id. at 8-9.

${ }^{99}$ See R. Dworkin, supra note 1, at 20-21 (discussing the secondary rules that guide the actions of officials).

100 See id. at 35.

101 See id. at 35-36. 
rights of individuals, in the now familiar legal liberal lexicon, "trump" or delimit the power of majorities and communities. ${ }^{102}$ Obedience restrains and thereby moralizes power, aggression, and untrammeled selfinterested desire.

Third, the moral imperatives that constitute true law are nonpositivistic. The Rule of Law, in Corwin's provocative phrase, is a rule "made by no human hands." are not the products of any identifiable, positivistic legal procedure. ${ }^{104}$ Tribe insists that individual and minority rights "inhere" in the individual and are not "assigned" by any political actor. ${ }^{105}$ More abstractly, Fried's categorical duties, rights, and imperatives that bind decisions in a true legal system are, like rules of logic and syllogistic reasoning, similarly not the product of any individual's fiat. ${ }^{108}$ Individual and minority rights, although acknowledged by the Constitution, existed prior to and hence transcend that positivist expression. ${ }^{107}$ It is in this sense that "law," properly understood, is "autonomous" from politics. Unlike politics, such laws are not the product of power. They are neither "positive" nor "posited."

Finally, these nonpositivistic, apolitical, and unwilled imperatives are, nevertheless, human creations. The Rule of Law may be made by

102 See supra note 96 and accompanying text.

${ }^{103}$ Corwin, supra note 4, at 152.

304 See R. Dworkin, supra note 1, at 41-42.

105 See Tribe, supra note 6, at 596.

108 Thus Fried argues that moral rights, duties, and imperatives inhere by virtue of our moral personality, that they are not the sorts of things that can be assigned for instrumental reasons such as efficiency, and that where moral law and positive law conflict, moral law must override positive legalistic mandates. See C. FRIED, supra note 12 , at $97-100,108-24$.

${ }_{107}$ In reading the American Declaration of Independence, Jeremy Bentham wondered why, if rights were inalienable, they needed to be protected by positive law. He concluded that the rights thesis incorporated in the Declaration of Independence was "too ridiculous to deserve any notice." AN ANSWER TO THE Declaration of THE AMERICAN CoNGress (London 1776) (published anonymously, but attributed to Bentham); see also Hart, Law in the Perspective of Philosophy, 51 N.Y.U. L. Rev. 538 (1976) (examining current American legal thought in light of Bentham's work and criticizing the work of Nozick and Dworkin).

The modern American natural law writers are all, in some sense, seeking to vindicate the coherence of the "inalienability" of our rights against Bentham's claim. Tribe sees rights as more than positivistically assigned because they "inhere" in our personhood, see supra note 92 , while Dworkin argues, with only slightly greater recognition of the importance of institutional history, that rights are as they are, regardless of the Supreme Court's pronouncement on their content. See R. Dworkin, supra note 1, at 211 ("We cannot assume, in other words, that the Constitution is always what the Supreme Court says it is."); id. at 214-15 ("A citizen's allegiance is to the law, not to any particular person's view of what the law is .... [I]f the issue is one touching fundamental or political rights, and it is arguable that the Supreme Court has made a mistake, a man is within his social rights in refusing to accept that decision as conclusive."). 
no identifiable human hands, but it is still ours. It is a human, not a divine or natural invention. Legal principles are not determined by any positivistic or political legal procedure, but they nevertheless emerge from human history and community. As Dworkin insists, rights are not the contents of a transcendental strongbox in the sky. ${ }^{108}$ Individual rights are both derived from and ultimately ensure collective life and individual security. Thus, paradoxically, the obedient self-restraint and renunciation of power that characterize decisionmaking under "law" represent both an act of freedom from identifiable, positivistic, political, personal, or historical authority and an act of obedience to an ahistorical authority that has in some sense emerged from the community's will.

\section{B. Freud's Defense of Legal Liberalism}

The antinaturalistic and intuitive methodology of legal liberalism undermines its insistence on the morality and autonomy of law in two ways. First, legal liberalism pairs its antipositivist autonomy claim with the assertion that moral rights and principles nevertheless emerge from human history and community without explaining how this apolitical legal system came about. No history of the Rule of Law has been provided to explain its independence from political history. As a consequence, legal liberalism is vulnerable to a particular kind of historical skepticism. What the legal liberal identifies as an act of transcendental legal reason is easily revealed by critics to be an historical and political act of will. The legal liberal cannot, when confronted with particular cases, maintain her general claim that law is indeed divorced from the realm of power and politics.

Second, legal liberalism has not explained why the legal rights and principles that constitute the Rule of Law take an imperative or deontological form. The moral obligation to obey law is felt as a restriction on our natural inclinations rather than as an extension or qualification of them. Why? Although most legal liberals agree that moral rights and principles restrict rather than extend the power of legal actors, the reason that such restriction is necessary to moral governance remains unexamined. As a consequence, the insistence on the morality of fidelity to law is vulnerable to normative skepticism. What the legal liberal

108 See R. DwORKIN, supra note 1, at 36 (noting that principles get support not from external sources, but from community practice and understanding); $c f$. Southern Pac. Co. v. Jensen, 244 U.S. 205, 222 (1916) (Holmes, J., dissenting) ("The common law is not a brooding omnipresence in the sky ... ."), quoted in Fiss, supra note 5, at $746 \mathrm{n} .15$. 
describes as a moral act of compliance with legal rights and principles is easily recast by her critic as morally neutral (or worse) acquiescence in the command of some political actor. The legal liberal has not convinced the critics that the act of renunciatory obedience by those in power carries any normative significance.

Freud's historical account of the Rule of Law and his description of human nature supply a response to these criticisms fully consistent with legal liberal ideology. First, Freud's history of law gives content to the legal liberal's intuition that legal rights and principles are created by the community, but are nevertheless autonomous from politics. In the story of the brothers' rebellion against their father, Freud shows that the Rule of Law is the collective's reconstitution of an earlier authority that had been autonomous from the political will of the community. Freud's history also explains why the Rule of Law is correctly felt to be a limit on, rather than a manifestation of, power. First, the Rule of Law is, substantively, the reconstitution of an authoritative command to renounce power. Second, the reconstitution of the Rule of Law embodies the community's triumph over the despotism of personal power. Obedience to the Rule of Law, then, is not a political act-it does not require the weaker to bend to the tyranny of the stronger's will. Instead, law requires obedient renunciation-not suppression-by the human will through the internalized authority of an imperative, communal, and self-consciously apolitical command.

Freud's view of human nature also justifies the legal liberal's determination that obedience to the nonpositivistic norms of law is necessary to moral progress. Freud equates morality with the work of Eros, that work being the preservation of collective life through the formation of larger social units. The individual's renunciation of desire through obedience to impersonal norms is strategically necessary to the erotic work of civilization: the collective can survive and progress only if each individual renounces instinctual aggression. Thus, obedience to ahistoric commands is a moral imperative that minimizes or neutralizes the threat to collective survival posed by our aggressive desires. The communal reconstitution of the moral imperative that the powerful obey impersonal norms emerges from Freud's jurisprudence as a life-preserving strategy of the weak and of the collective. Given this framework, the legal liberal's insistence on the moral necessity of obedience to the Rule of Law emerges as eminently rational.

Freud's theory of the origins of law is an illuminating prototype for the legal liberal's mythical version of early American politico-legal 
history. ${ }^{109}$ Like the ancient brother horde, America revolted against and declared its independence from the British king, a superior parental figure who, like the primal father, was both protective and exploitative. When we discovered the potency of collective action, we revolted and overcame the paternal figure. After the revolution, we found that the same aggressive power with which we had vanquished the British king posed a threat to our collective survival. The Articles of Confederation-the early nation's "horizontal" agreement-were not strong enough to counter our powerful and anticollective aggressive instincts. In the period of post-revolutionary uncertainty, we remembered our method for neutralizing aggression prior to independence. As British subjects, we had renounced our aggression through acts of resentful obedience in order to ensure the crown's protection and nurturance. To employ the same strategy in post-revolutionary times, we needed to constitute an authority to whom we could offer subsequent obedience. When we wrote and ratified the Constitution of the United States, we in effect reconstituted the deposed authority in totemic form.

The Constitution, like the Rule of Law, is the community's source of authority as well as the community's creation. The legal liberal's attitude toward constitutionalism is thus perfectly parallel to the attitude of the Freudian brothers toward the Rule of Law. First, the Constitution protects us by ruling over us, and equalizes us by commanding renunciation of our instinctual aggression. Second, despite its authority, the Constitution is itself non-aggressive, nonthreatening; it is protective and, above all, depersonalized. Third, because it is self-created and selfimposed, our obedience to the Constitution represents an advance beyond our submission to the British king. We submit to the Constitution and obey it, and at the same time assert its existence as evidence of our freedom from authority.

109 If my argument that Freud's theories should be used to undergird liberal theory is right, this exercise may in turn explain the legal liberal belief, most clearly stated by Dworkin, in the coincidence of constitutional law with liberal ideals, and the convergence of American history with liberal progressivism:

The liberal ... needs a scheme of civil rights whose effect will be to determine those political decisions that are antecedently likely to reflect strong external preferences and to remove those decisions from majoritarian political institutions altogether. The scheme of rights necessary to do this will depend on general facts about the prejudices and other external preferences of the majority at any given time, and different liberals will disagree about what is needed at any particular time. But the rights encoded in the Bill of Rights of the United States Constitution, as interpreted (on the whole) by the Supreme Court, are those that a substantial number of liberals would think reasonably well suited to what the United States now requires ....

R. Dworkin, supra note 12 , at 197. 
The integration of Freud's views on law and human nature with liberal thought would free legal liberalism from the paradox that now bedevils it. The removal of paradox, of course, has its price. If Freud's account of our nature is wrong, his defense of legal liberal commitments fails. We may be less aggressive or more empathic than Freud assumed, or, worse yet, we may be incapable of renunciatory obedience. The gain in coherence, however, is well worth the price of contingency. Freud's description of our natural inclination toward law rationalizes the faith of legal liberals and provides the means by which that faith may be verified or falsified. Freud's naturalistic narrative suggests at least three areas of inquiry for liberal theorists. First, if legal liberals are unpersuaded by Freud's account of the autonomy and morality of law, they should propose an alternate theory of human nature, perhaps one more in line with modern views, that can give substance to liberal intuitions. Second, if legal liberals are convinced by Freud's description of our nature, they should recharacterize their understanding of the morality and autonomy of law in order to bring it into harmony with Freud's legal teachings. Finally, if legal liberals can find no plausible characterization of our nature to support their intuitive commitment to the morality and autonomy of law, the intuitions themselves must be seriously reconsidered and perhaps abandoned.

\section{Contrasting Visions and Competing Methods: Critical ASSESSMENTS OF THE RULE OF LAW}

Many of legal liberalism's modern critics are less adverse to naturalistic explanations than are legal liberals themselves. Thus, the critiques of liberalism and the theories of law offered by non-liberal feminists, critical legal scholars, and legal economists often rest on relatively explicit descriptions of human history and nature. These descriptions diverge sharply from the picture of our history and nature relied on by Freud. Each of the following three sections therefore begins by contrasting the Freudian conception of personality with the views embraced by these non-liberal theorists. Each section then argues that Freud's response to liberalism's critics is stronger than that set forth by a representative liberal theorist, because Freud's analysis is grounded on facts about our history and nature, while the liberal response is grounded on intuitively grasped moral truths. Even if Freud's naturalistic argument fails to convince-perhaps because his understanding of the morality of the Rule of Law rests on beliefs that we now take to be false-his arguments are more coherent than the intuitive claims set forth by legal liberals. The relative superiority of Freud's response, I will argue, is in each case a result of Freud's willingness to employ a 
naturalistic method of justification that the modern liberal theorist deplores.

The first subsection contrasts Freud's account of our legal personality with the depiction of our nature drawn by the law-and-economics movement, and then compares Freud's response to the economist with that of Laurence Tribe. The second subsection contrasts Freud's vision of human nature with that embraced by some (but by no means all) critical and feminist legal scholars, and then contrasts Freud's defense of the Rule of Law against their attack with that of Charles Fried. Finally, the third subsection examines what is often portrayed as the most dangerous attack on the Rule of Law-the critical legal scholars' deconstruction project. Freud offers at best a limited response to the deconstructionist's claim, but one that is superior to the inarticulate fear expressed by Owen Fiss. Freud's analysis offers a coherent explanation of the liberals' panic in the face of the deconstructionist threat. If Freud's analysis of our need for authoritative law is correct, and if the deconstructionist's understanding of the impossibility of objective interpretation is also correct, then the legal liberals are prudent to run for shelter.

\section{A. The Law-and-Economics Movement: Nature and Civilization Before the Deed}

The modern legal economist's distinctive analysis of the nature of law rests on a denial of Freud's claim that individual desire, instinctual or otherwise, is socially dangerous or morally problematic. ${ }^{110}$ In contrast to Freud's description, the legal economist describes an individual who lacks an instinct for death and destruction ${ }^{111}$ and who thus lacks socially dangerous aggressive desires. In the world of law and economics, the desires of the powerful do not constitute a threat to social life and do not raise a "problem of power." On the contrary, the desires of the individual are the exclusive source not of danger, but of value to the

110 Economics "assume[s] that man is a rational maximizer of . . . his 'self-interest." " R. POSNer, Economic ANalysis of Law 3 (2d ed. 1977). Posner admits that this basic economic assumption "seems contradicted by introspection and other experience of everyday life" and that economic assumptions in general "are to some extent . . . unrealistic as descriptions of human behavior." Id. at 12. These assumptions are nevertheless justified for economists because "lack of realism [in assumptions] . . . is the essential precondition of theory." Id. at 13.

111 For example, an economist explains crime, including violent crime, as the result of benefits to the criminal from committing a crime that are greater than the costs imposed. See id. at 164. Under this analysis, no more is needed to reduce crime than an "increase in either the severity of punishment or the likelihood of its imposition . . . " Id. at 6. 
community. Maximal satisfaction, rather than renunciation, of individual desires is thus value maximizing as far as the community is concerned. ${ }^{112}$ Thus, there is no need for the powerful individual to renounce desire and no need for the "artificial equality" facilitated by such renunciation. While motivational and cognitive disabilities may require the regulation of activity, ${ }^{113}$ our nature does not necessitate renunciation of desire or equalization of strength. Indeed, the legal economist denies the wisdom of "artificial equality"- the goal of the Rule of Law-and the need for renunciation-the reason for the Rule of Law - and hence denies the legitimacy of the Rule of Law itself.

If true, the legal economist's description of our nature thoroughly rebuts Freud's "history" of law. In a state of nature following the lawand-economics model, the strong would not oppress the weak; the weak would not resent the powerful; there would be no cooperative revolt by the sons against the father, no "beginning deed," and no remorse. Consequently, no totem of any kind-legal, moral, or religious-would emerge from the natural state. There would simply be no need for totems and no need for "subsequent obedience" to reconstituted authority. The legal economist's modern world is consequently populated by fully embodied fathers and big brothers; it is ruled by the fathers' commands and enriched by the big brothers' productivity. Since there are no socially and morally dangerous aggressive desires, the weak and the strong coexist-in markets, workplaces, homes, and public life. The legal economist's world is free from the imperatives of impersonal totemic authorities. Instead, it is ruled by the nonproblematic desires and commands of the strong.

To the legal economist, law is decidedly not a communal reconstitution of the vanquished father's personal power. In the legal economist's world of innocent desire, "law" is determined by the desires of the strong and is the outcome of their victories in the political arena. ${ }^{114}$

\section{See id. at 17-18. Frank Michelman explains that}

[t] he method of valuation [used by economists] remains . . . strictly individualistic and private. Value is what the affected individual experiences; it is transrational, not amenable to public or intersubjective discussion or determination. ... [A]s an ethical criterion [it] is at bottom felt to be individualistic in orientation: a steadfast practice of maximizing private values, as defined by individual preferences, is thought to promise the maximum attainable long-run satisfaction of everyone's private preferences, just as a bigger pie promises bigger slices.

Michelman, Norms and Normativity in the Economic Theory of Law, 62 MinN. L. REv. 1015, 1020 (1978).

11 See infra note 119.

114 See Easterbrook, The Supreme Court, 1983 Term-Foreward: The Court and the Economic System, 98 HARv. L. REv. 4, 60 (1984) ("II]f powerful groups are 
In Freudian terminology, these victors are our "fathers," and their commands, not the commands of the impersonal totem, constitute the "law" that judges must enforce. Thus, Judge Easterbrook insists, the judge must obey the powerful voices of the victors: the historical framers, Locke and Montesquieu, the winners of the Civil War and the Revolution, the federalists, the sponsors of enacted legislation, the authors of historical judicial decisions, and successful amenders of the Constitution. We must obey these voices not because they articulate a normatively correct prescription for government-not because slavery is wrong or because the Givil Rights Act is just. We must obey the voices of our "fathers" because they were victorious. At the same time, we cannot obey Rousseau, the antifederalists, the pre-Civil War South, sponsors of unsuccessful legislation, failed attempts at constitutional amendment, or dissenting decisions in earlier case law. Why? Again, it is not because they were wrong on the merits, but because they lost. Rousseau, Laurence Tribe, and the antifederalists bet on the wrong horse; thus, they cannot speak "with authority," and their words are not law.

Judges who base their decisions on any ground other than the prevailing political authority are acting ultra vires. According to Judge Easterbrook, to follow some moral or rational authority because it better approximates the judge's own notion of good or right is to reconstitute a totemic of authority void of all legitimacy:

Judges have no authority to reconstitute the values of the people or to exalt redistribution at the expense of com-

denied the outcome they want most, they may find other ways to accomplish their ends ...."). The principle that the law to be followed is the law of the victors is derived from the legal economist's notion of the nature of legislation. The legal economist identifies two types of statute: public interest and private interest. Where a statute is "designed to overcome 'failures' in markets and to replace the calamities produced by unguided private conduct with the ordered rationality of the public sector," it will be labeled a public interest statute, and should be construed broadly to fulfill the aims of the statute. $I d$. at 15 . Private interest statutes, on the other hand, are simply another type of commodity demanded by different groups seeking to appropriate benefits for themselves while they ignore the interests of society as a whole. See id. at 15-16. The private interest statute should be narrowly construed to achieve its limited purpose, thus respecting the deal struck by the victorious interest group. See id. at 46,54 . If a statute results from the compromise of several interests, its interpretation should respect the wishes of the winning coalition regardless of the costs that may fall on other parties. See id. at 54 (analyzing Norfolk Redev. \& Hous. Auth. v. Chesapeake \& Potomac Tel. Co., 464 U.S. 30 (1983) (finding that a telephone company was not entitled to compensation under a federal statute because it was not part of the coalition that had obtained the legislation)). Adjudication that abides by these distinctions is thought to "promote efficiency and avoid the error costs incurred in thwarting the will of the majority." Comment, Posnerian Jurisprudence and Economic Analysis of Law: The View from the Bench, 133 U. PA. L. REv. 1117, 1129 (1985) (footnote omitted). 
peting objectives selected by the political branches. Our Constitution is based on the ideas of Locke and Montesquieu, not the view of Rousseau that the state should imbue its citizens with the "true" values they "ought" to hold. The framers were skeptical about both the existence of such values and the wisdom of trusting the government to choose among them. They rejected the arguments of the anti-Federalists, which were very similar to those of Rousseau and Professor Tribe. ... The choice was to recognize and rely on the self-interest of factions-public and private-rather than to scorn faction and seek the instruction of Platonic guardians.

The Constitution demands that all power be authorized. It is not enough to say that judicial decisions are about "how we define our society and specify much about what we stand for and what sort of country we wish to become." "We the People" speak through the Constitution itself, through representatives in the legislature, through the amending process. . . . Judges applying the Constitution . . . must take their guidance and authority from decisions made elsewhere. Otherwise they speak with the same authority they and Professor Tribe and I possess when we fill the law reviews with our speculations and desires: none. And the other branches owe no obedience to those who speak without authority. ${ }^{115}$

In the legal economist's view, judicial determinations of the correct law to be applied that are based on vague notions of fundamental rights, or on the persuasiveness of a litigant's reasoning, are unauthorized and illegitimate. There are no "sacred values" hidden in the "implications" of constitutionalism. Argument has no greater role than the losers in the political process. The judge's power is granted and defined by the power of personal authorities, not by the persuasive force of a well-reasoned law review article or dissenting opinion. The law review article, no matter how compelling, speaks "without authority." The quality of the dissenter's "reasoning" does not change the fact that she lost or that the law review author has garnered no votes. Any such "reconstitution" of authority is an attempt to undermine the superior strength of the embodied fathers. The legal economist-though the first to obey the imperative of the new authority, should the mutiny prove successful-will brook no secret plan of mutiny. ${ }^{116}$

115 Easterbrook, Method, Result, and Authority: A Reply, 98 HARv. L. REv. 622, 628-29 (1985) (footnotes omitted) (quoting Tribe, supra note 6, at 595).

116 "[J] udges have not been charged with imposing their substantive views on the 
The law-and-economics movement also holds that courts, while enforcing the commands of the father, should formulate rules that maximize the satisfaction of instinctual desire. The natural world can cause a lot of pain-and a lot of hunger-and the purpose of private life is to minimize that pain by maximizing the wealth we extract from nature. We are homogeneously and monochromatically "programmed"117 to seek pleasure and to remold the world to serve this end. In Freudian terminology, the "pleasure principle" dictates that we will do so. ${ }^{118}$ However, satisfaction of the pleasure principle is modified by the "reality principle."119 In Easterbrook's words, "All good things are scarce. Self-interested conduct is the handmaiden of scarcity. These are facts of life."120 These facts of life-Freud's reality principle-underlie the law's second function: to bring together, through regulation, desire and reality. ${ }^{121}$ Legal regulation is necessitated by the reality principle and should be directed toward greater satisfaction of instinctual desire, not toward the renunciation of desire or the prohibition of desired objects. We regulate the satisfaction of desire so that more desire can be satis-

economic system. Judges' claim to authority rests on a plausible demonstration that they are faithfully executing decisions made by others." Easterbrook, supra note 114, at 60 (footnote omitted).

117 This is Freud's word. See S. Freud, Civilization, supra note 9, at 23.

118 The pleasure principle holds that the operation of the mental apparatus is directed to the achievement of pleasure and the reduction of "unpleasure." See S. Freud, Pleasure Principle, supra note 60 , at 1 . The achievement of pleasure is accomplished by lessening "the amount of stimulation present in the mental apparatus." S. FreUd, GENERAL INTRODUction, supra note 60, at 365.

119 The difficulties of life in the external world, social necessity, and the "ego's instincts of self-preservation" lead to the replacement of the pleasure principle by the reality principle. See S. FreUd, Pleasure PrinciPle, supra note 60, at 5 . While the ultimate aim of the reality principle is pleasure, the task of avoiding pain is of almost paramount importance. See S. FreUd, General InTRODUCTION, supra note 60, at 365. The reality principle orients the ego to delayed gratification, temporary tolerance of unpleasure, and the "abandonment of a number of possibilities of gaining satisfaction." S. Freud, Pleasure Principle, supra note 60, at 6 . All of this is in the service of the ultimate attainment of pleasure, "which is assured by [the ego's] realization of fact [and] its relation to reality." S. FREUd, General InTroduction, supta note 60 , at 365 .

${ }^{120}$ See Easterbrook, supra note 115, at 622.

121 The law-and-economics school postulates that the individual is a "rational maximizer of his . . . 'self-interest.' " R. PosNER, supra note 110, at 3 . The economic reality principle recognizes that "resources are scarce in relation to people's desires to consume them. As a result, people must make choices between various resources or activities." Comment, supra note 114 , at 1119 . When the desires of economically rational individuals conflict, the law steps in to regulate their behavior and achieve the most efficient result by altering the incentives that stimulate their actions. See R. PosNER, supra note 110, at 190 . The regulatory purpose of law is to "allocate responsibilities between people engaged in interacting activities in such a way as to maximize the joint value, or, what amounts to the same thing, minimize the joint cost of the activities." Id. at 179. 
fied. The courts should help big brother increase the size of the pie through productivity; they should not engage in paternalistic inquiries about the "fairness" or "unfairness" of the distribution of wealth and power between big brother and his littler siblings. ${ }^{122}$ Power and productivity release the wealth of the natural world. ${ }^{123}$ They do not release aggressive, sadistic, masochistic, or destructive instinctual cravings.

Since the individual has no dangerously antisocial aggressive instinct, there is no aggressive instinct turned inward in the form of conscience, superego, or guilt. Accordingly, legal economists deny the moral imperative and the renunciatory dimension of the Rule of Law and of its totemic progeny. ${ }^{124}$ To be made intelligible to the legal econ-

122 As Judge Easterbrook explains it:

Lawyers routinely make "policy" arguments to courts; legislatures invoke instrumental claims to show that their statutes are "rationally related" to some objective that they attain by changing people's incentives. It is nonetheless startling how often these arguments collapse to claims about "fairness," which in the law almost always means some appeal to an equitable division of the gains or losses among existing parties given that certain events have come to pass. Fairness arguments are ex post arguments, and few lawyers or judges are comfortable arguing about or deciding a case without invoking the ideal of fairness. Who is for unfairness?

The degree to which fairness or other ex post arguments dominate in legal decisionmaking is directly related to the court's assumptions about the nature of the economic system. Judges who see economic transactions as zero-sum games are likely to favor "fair" divisions of the gains and losses. If the stakes are established in advance and will not be altered by courts, why should judges harshly require one party to bear the whole loss or allow another to take the gain? Yet if legal rules can create larger gains (or larger losses), the claim from fairness becomes weaker. The judge will pay less attention to today's unfortunates and more attention to the effects of the rules.

Often only this form of attention protects the interest of increased productivity. The people who might be affected by the rules are not before the court and may not even be in the affected business (yet). The interests of prospective consumers and producers are diffuse, too much so for any one person or group to participate in the litigation. The judge is the representative of these future interests.

Easterbrook, supra note 114, at 11-12 (footnote omitted) (emphasis added).

Rather than inquiring into a law's "fairness," "[n]ormative economics holds that a policy, law, etc. is to be judged by its effect in promoting 'welfare." " Posner, Utilitarianism, Economics, and Legal Theory, 8 J. Legal Stud. 103, 104-05 (1979). Posner defines "welfare" in this sense as "value' in the economic sense of the term, or more clearly I think, as 'wealth." "Id. at 119.

123 See Easterbrook, supra note 114, at 58-60.

124 Denial of the obligatory moral and imperative force of totemic reconstitutions of authority is what one would expect, historically, of instinctually non-aggressive brothers before the deed. There has been no intolerable suppression of the weak by the strong, no act of patricide, no successful rebellion against the aggression and destructiveness of personal authority, no remorse, and no guilt. There is, then, no need for "subsequent obedience" to the reconstituted impersonal authority of the Rule of Law. Compare, e.g., Moore, Moral Reality, 1982 WISc. L. REv. 1061, 1067-70 (attacking 
omist, the content of the Rule of Law must be retranslated into terms consistent with the rational, economic work of communal living. Where such a translation is not feasible, the moral imperative must give way to economic goals. This translation recurs in virtually every legal sphere. Criminal, tort, contract, and public law norms are consistently reinterpreted in a way that strips them of their moral and renunciatory content. Just as there is no room for totemic reconstitutions of impersonal authority in the public world, there is no need for guilt-induced acts of subsequent obedience to internalized authority in the private world. Thus, it is no sin-it is not morally wrong-to break promises, ${ }^{125}$ to let one's cattle trample the farmer's crops, ${ }^{128}$ to act carelessly in ways that hurt others, ${ }^{127}$ or to kill without justification or excuse. ${ }^{128}$ These acts may require regulation if their performance hinders greater satisfaction of desire: if, that is, such extra-market regulation is required by the reality principle. ${ }^{129}$ Committing these acts is not, however, immoral. Indeed, when the correct "costs" are internalized and there is profit to be made, the actor should be free to break the promise, let the cattle

the absence of moral content in utilitarian theory) and C. FRIED, supra note 12, at 3053 (arguing for a moral content of acts of direct harm) with $R$. PosNeR, supra note 110 , at 65-71, 163-76 (discussing the economic rather than moral function of criminal and contract law) and Coase, The Problem of Social Cost, 3 J.L. \& Econ. 1 (1960) and Easterbrook, supra note 115, at 627-29 (discussing the economic desirability of certain acts).

125 See R. POSNER, supra note 110 , at $65-80$. In contract, private promises are stripped of their imperative authority if they interfere with the shared rational work of communal living. For the legal economist, the promise carries no moral obligation of performance. Instead, the promise presents the promisor with a choice of options, not an imperative, and it facilitates satisfaction of desire, not renunciation.

${ }_{126}$ See Coase, supra note 124, at 2-6 (analyzing the economics of the relationship between a cattle rancher and a crop farmer in the absence of fences). The legal liberal's moral intuition that ranchers should not let their cattle trample on farmers' land has no authority when it interferes with the rational need-satisfying work of communal life. The legal economist denies the moral content of the imperative, as well as the renunciatory and mandatory dimensions. No moral reason dictates the rancher's course of action, no imperative can or should restrain his choice, and no rule can mandate renunciation of his desires.

127 See R. POSNER, supra note 110, at 122-23 (describing Learned Hand's negligence formula).

${ }^{128}$ See id. at 163-75. While murder is illegal for the liberal theorist because of her intuitive certainty that it is wrong to kill, for the legal economist murder is illegal because it interferes with the rational work of communal living: it is not wealth maximizing. The legal economist denies the moral content of the imperative-the "wrongness" of murder; denies the imperative dimension of the prohibition-that we must not kill; and denies its renunciatory import-that the murder prohibition mandates renunciation of choice, not the enlargement of our power.

129 "The economic analysis of rights seeks to discern which assignment of rights in the real world of costly and impacted bargaining best approximates the attainment of efficiency . . ." C. FRIED, supra note 12, at 91 . Breaking promises is thus regulated in the contract setting because real-world transaction costs (for example, the cost of finding out that someone has broken a promise) would otherwise result in inefficiencies. 
trample the crop, or commit the rape. The legal sanction is not grounded in and should not be interpreted in light of any moral "thou shalt not." It is grounded solely in, and should be interpreted solely in light of, the neutral economic task of communal living-the reaping of pleasure through the cooperative or competitive manipulation of nature.

The legal economist denies the need for renunciation of desire through obedience-she sees no reason, moral or otherwise, to restrain desire at all. In exalting historical victories of public strength and acquiescing in the triumphs of private power, the law-and-economics school asserts not so much the pre-Socratic doctrine that "might makes right" as it does the claim that "might is innocent."130 The desires of the strong are not a threat to the community's collective survival. There is no problem of power that cannot be solved by regulatory rules. Our fathers are protecting us, not oppressing us. The revolutionary-federalist-founding father-fourteenth amendment-Civil Rights Act coalition of fathers has maintained our collective, public identity. Our stronger brothers-those with superior bargaining power in the private realm-have desires that serve the community. Father rules us while big brother increases the size of the pie. In the economic world, instinctual desire is benign, and hence the instincts of both the strongest and the stronger should be set free.

1. Freud's Response: The Pleasure Principle and the Need for the Totem

Like the modern economist, Freud hypothesized that the individual strives to maximize her pleasure within the constraints of reality. As a result, the task of life has an economic component:

[People] strive after happiness; they want to become happy and to remain so. This endeavour has two sides, a positive and a negative aim. It aims, on the one hand, at an absence of pain and unpleasure, and, on the other, at the experiencing of strong feelings of pleasure. In its narrower sense the word 'happiness' only relates to the last. In conformity with this dichotomy in his aims, man's activity develops in two directions, according as it seeks to realize-in the main, or

130 "[T]he virtue of the Pareto principle resides in its alleged neutrality . . . . [A] conflict of interest . . . is symmetric in all relevant respects, and the determination of which of the parties ought, if possible, to compensate the other is . . . held to be of no interest to economists." Mishan, Pareto Optimality and the Law, 19 OxFORD ECON. PAPERS 255, 279-80 (1967), quoted in C. FrIED, supra note 12, at 88 n.*. 
even exclusively - the one or the other of these aims. ${ }^{131}$

Like the modern legal economist, Freud derived the origin of law and civilization from the fundamental premise outlined above: that all individuals pursue pleasure but are constrained by reality. The prototypical source of pleasure-genital satisfaction-led to the formation of the family, the first social unit. ${ }^{132}$ At the same time, reality indicated that the simple pursuit of pleasure was not enough to sustain life. By necessity, people determined that they could satisfy their hunger-their greatest source of "unpleasure"-by efficient manipulation and control of nature. ${ }^{133}$ Learning how to procure food most effectively led to an important discovery: the value of cooperative work and communal living. ${ }^{134}$ "The communal life of human beings had, therefore, a two-fold foundation: the compulsion to work, which was created by external necessity, and the power of love . . ."135 This picture of economic relations as the root of civilized life informed Freud's hypothesis that love and necessity-"Eros and Ananke"-are the "parents of civilization."138

In Civilization and Its Discontents, Freud qualifies the economic account of civilization's origins. ${ }^{137}$ The "hunger and love" picture of civilization, Freud argues, explains the development of families and the

192 S. Freud, Civilization, supra note 9, at 23.

132 Freud explains that

in his ape-like prehistory, man had adopted the habit of forming families, and the members of his family were probably his first helpers. One may suppose that the founding of families was connected with the fact that a moment came when the need for genital satisfaction no longer made its appearance like a guest who drops in suddenly, and, after his departure, is heard of no more for a long time, but instead took up its quarters as a permanent lodger. When this happened, the male acquired a motive for keeping the female, or, speaking more generally, his sexual objects, near him; while the female, who did not want to be separated from her helpless young, was obliged, in their interests, to remain with the stronger male.

Id. at 46 (footnote omitted).

13 See id. (" $[\mathrm{P}]$ rimal man ... discovered that it lay in his own hands . . . to improve his lot on earth by working .....").

1s4 As Freud put it, "The other man acquired the value for him of a fellowworker, with whom it was useful to live together." Id.

${ }^{185}$ Id. at 48 . Freud goes on to assert that

[t]he first result of civilization was that even a fairly large number of people were now able to live together in a community. And since these two great powers [of work and love] were co-operating in this, one might expect that the further development of civilization would proceed smoothly towards an even better control over the external world and towards a further extension of the number of people included in the community.

Id.

1 ss Id.

137 See id. at 55, 69. 
legal regulation of activity, but it does not explain other facts. It does not, for example, explain the renunciatory forms revealed in law, religion, morality, and conscience, or the correlative sense of guilt and the feeling of discontent that pervade civilized life. ${ }^{138}$ More important, "hunger and love" cannot accommodate what became for Freud an incontrovertible fact: the individual's instinct for death and aggression. From his historical speculations, and from his clinical study of masochistic and sadistic phenomena, Freud concluded that, in addition to our desire for pleasure-or, in the modern legal economist's jargon, our desire for wealth-we also desire the destruction of the living world both around and within us. ${ }^{139}$ It is this instinctual desire for death, destruction, and "stillness" that gives rise to our aggressive inclinations against both ourselves and others. The mature Freud concluded that the economic conflict between the pleasure principle and the reality principle is not the fundamental conflict against which life is played out. The essential conflict is between the individual's instinctual desire for life and instinctual desire for death..$^{\mathbf{1 4 0}}$

Freud's insistence on the individual's inherent aggression is thus his critical point of departure from the law-and-economics theorist. The legal economist believes that the strong individual-the big brother discussed above-is motivated solely by the desire to gain wealth and pleasure, and that this desire is ultimately (when regulated) beneficial to the community. Freud, on the other hand, depicts a strong individual who is primarily intent on harming weaker individuals, even when it accords him no economic advantage:

He seems not to have the least trace of love for me and shows me not the slightest consideration. If it will do him any good he has no hesitation in injuring me, nor does he ask himself whether the amount of advantage he gains bears any proportion to the extent of the harm he does to me. Indeed, he need not even obtain an advantage; if he can satisfy any sort of desire by it, he thinks nothing of jeering at me, insulting me, slandering me and showing his superior power;

138 See $i d$. at 55-63.

1s9 Starting from speculations on the beginning of life and from biological parallels, I drew the conclusion that, besides the instinct to preserve living substance and to join it into ever larger units, there must exist another, contrary instinct seeking to dissolve those units and to bring them back to their primaeval, inorganic state. That is to say, as well as Eros there was an instinct of death. The phenomena of life could be explained from the concurrent or mutually opposing action of these two instincts.

Id. at 65-66 (footnote omitted).

${ }_{140}$ See supra text accompanying notes $48-52$. 
and the more secure he feels and the more helpless I am, the more certainly I can expect him to behave like this to me. ${ }^{141}$

In Freud's world of uninhibited desire, the strong deprive the weak of pleasure and expel those who challenge their superior status. The relatively powerless, while not undergoing the painful renunciation of instincts required today under a Rule of Law, undergo the even more brutal process of suppressing their instincts. ${ }^{142}$ The world that emerges is not the one of productive work and satisfied desires described by the economists. It is one of individual freedom for the strong and of brutal, suppressive severity for the rest. If Freud's description of our desires is right, then the desires of the powerful must be guarded against, not maximized.

\section{The Need for the Totem: The Liberal Rejoinder}

Laurence Tribe's representative and often eloquent liberal response to Judge Easterbrook's attack on the Rule of Law rests on two principal arguments. The first is conceptual. Law consists, says Tribe, of nonpositive, autonomous, individual "rights" that inhere in the individual's organic history:

Being "assigned" a right on efficiency grounds, after an appraisal of the relevant cost curves, hardly satisfies the particular human need that can be met only by a shared social and legal understanding that the right belongs to the individual because the capacity and opportunity it embodies are organically and historically a part of the person that she is, and not for any purely contingent and essentially managerial reason. ${ }^{143}$

The second argument is normative. The Court should act as the community's "reconstituted moral authority"-the same role that Freud ascribed to the totem, religion, conscience, and ultimately the Rule of Law. Tribe rejects the notion, at least in the context of consti-

141 S. Freud, Givilization, supra note 9, at 57 (emphasis added).

142 [I]n the primal family only the head of it enjoyed this instinctual freedom; the rest lived in slavish suppression. In that primal period of civilization, the contrast between a minority who enjoyed the advantages of civilization and a majority who were robbed of those advantages was, therefore, carried to extremes. As regards the primitive peoples who exist to-day, careful researches have shown that their instinctual life is by no means to be envied for its freedom. It is subject to restrictions of a different kind but perhaps of greater severity than those attaching to modern civilized man.

Id. at 62 .

I4s See Tribe, supra note 6, at 596 (footnote omitted). 
tutional adjudication, that judges should simply follow rules already set out for them by the political branches of government. To Tribe, it is the function of the courts both to give expression to community values and to shape and direct those values in new directions. The courts have the responsibility to define the kind of nation we become. ${ }^{144}$ To do so is not a usurpation of political power, but an exercise of judicial responsibility. Consequently, Tribe is critical of law-and-economics methods that "cannot address the question of what the chooser's system of ends should be. . . . [T]he core of the Supreme Court's function . . . must rotate precisely about these questions of value, not merely about questions of relative efficiency."145

Chief among the normative values that Tribe would have courts promote is the protection of the weak against the aggression of the strong. The rights that inhere in the organic history of every individual thus protect against, rather than embody, the commands of the political victor. In examining the decisions of one Supreme Court term, Tribe observed that the Court is becoming increasingly indifferent to the distributional impact of its decisions, a trend that Tribe sees as a derogation of its responsibility to empower the weak. ${ }^{146}$ The Court has in-

144 Thus, Tribe argues:

Treating a constitutional court's task as merely one of toting up marginal costs and benefits also ignores the crucial questions of what counts as a cost or a benefit-and who gets to decide that issue. The approach applauded by Professor Easterbrook thus fails to recognize the constitutive dimension of constitutional decisions: the fact that constitutional choices affect, and hence require consideration of, the way in which a polity wishes to constitute itself. In making such choices, we reaffirm and create, select and shape, the values and truths we hold sacred. Such decisions determine much about how we define our society and specify much about what we stand for and what sort of country we wish to become. Contrary to Professor Easterbrook's assumption, the constitutional decisions of courts-and, to a lesser but still significant degree, all legal decisions-serve not merely to implement "given" systems of acknowledged values, but also to define and reshape the values-indeed, the very identity-of the nation. A court not only chooses how to achieve preexisting ends, but also affects what those ends are to be and who we are to become.

Id. at 595 (footnote omitted).

145 Id. at 596 (footnote omitted).

168 The vital fact is that the Court's actions, like the steely cost-benefit analyses with which they comport so well, are sadly insensitive to constitutional concerns bearing on the distribution of wealth and power and to the broader constitutive dimensions of all legal decisions. Because it is those concerns and dimensions that should be most prominent on the agenda of a court dealing with constitutional issues, the Supreme Court's failure to take such concerns seriously is no less troubling if the cost-benefit patina is but a mask for substantive judgments arrived at through other means, than it is if the cost-benefit imagery genuinely mirrors what the Court understands itself to be doing.

Id. at 598 (footnote omitted). 
stead embraced a standard of neutrality that, in one exemplary case, upheld a regulation "that forbade the wealthy and the homeless alike to sleep in the memorial parks of the nation's capital."147 Apparent neutrality, Tribe argues, acts as a smokescreen to disguise the pervasive disempowerment of the poor and the empowerment of the rich. ${ }^{148}$ The Supreme Court's increasing utilitarianism has led it to dilute rights, on efficiency grounds, that had once been protected in order "to close the chasm that existed between [the] successful and sophisticated . . . and those less fortunate."149

Using these arguments, Tribe concludes that the principal function of the law is neither to regulate the private desires of big brother nor simply to enforce father's commands. The law should be the watchdog that protects the weak from the desires of the powerful, rather than a protector of those very desires. ${ }^{150}$ Unlike Freud, however, Tribe fails to support either of his conclusions. His conceptual claim that the individual possesses organic rights lacks a historical explanation, and his normative claim that we ought to protect the weak against the desires of the strong lacks a grounding in any specified description of our nature.

Freud's jurisprudence fills both gaps in Tribe's argument. First, Freud's history of law gives content to Tribe's claim that rights are a part of the individual's organic history. After the rebellion against personal authority, according to Freud, the successful revolutionaries er-

${ }^{147} I d$. at 602 (discussing Clark v. Community for Creative Non-Violence, 468 U.S. 288 (1984)).

148 See id. at 592-606.

148 Id. at 606.

${ }^{180}$ Thus, Tribe is justifiably critical of the Court's refusal to declare unconstitutional the application of a "no sleeping in the park" ordinance to a protest designed to give voice to the plight of the homeless. See supra note 147 and accompanying text. The Court's decision betrays the conscience of the totem:

The depth ... of Professor Easterbrook's [and the Court's] utilitarian lens is too shallow; adjusting the lens to extend its depth would bring uncomfortable questions into view, exposing not just the order and beauty of Lafayette Park but the pathos of those with no more hospitable place to sleep. Professor Easterbrook wishes to know, for example, what effect not enforcing the sleeping ban would have on future demonstrations by those with less of a message to impart. But he fails to ask what would happen if the voiceless reproach by homeless citizens encamped on the government's doorstep succeeded in inducing the appropriation of federal relief for their plight. Such demonstrations would then become unnecessary, and the Park Service's purpose in banning such camping-preservation of the park-would be well served. But Professor Easterbrook seems uninterested in examining that economic alternative, not to mention the distribution of power and wealth that puts homeless speakers uniquely at the mercy of the bureaucracy's interest in administrative efficiency.

Tribe, supra note 6, at 601 (footnotes omitted). 
ected a nonthreatening but protective reconstitution of the defeated father. The totem's function ever since has been to protect the weak from the strong and to do so through the enforcement of equalizing rights. Given Freud's history, the Rule of Law is indeed consistent with the inherence of these rights in the individual's organic history. Second, Freud's descriptive account of our nature justifies Tribe's fear of the desires of the powerful. The desires of our stronger brothers may sometimes be, as Easterbrook assumes they always are, directed toward maximizing the pleasure of life through the mastery of nature. But they are not necessarily so: the strong sometimes desire the sadistic control, death, and expulsion of the weak, and not simply their cooperative engagement in wealth-maximizing projects. When the strong are permitted to act on those desires, the social group shrinks, and the erotic task of civilization is frustrated.

Freud, unlike Easterbrook, believed that the powerful possess aggressive and sadistic inclinations, and that those instinctual desires pose a danger to civilization. He recognized, in short, the problem of evil. The aggressive instinct renders desire and its objects morally problematic, and it renders inequality of strength socially dangerous. Given Freud's view of human nature and desire, the moral role of law, as with all other totemic institutions, is to fight the evil that flows from our aggressive desires. If Freud is right about unrestrained power and the quality of life in a world without the Rule of Law, then, because some individual desires are hostile to civilization, Tribe is right to insist that law should not simply maximize those desires. Instead, the law should protect each member of the society against the various forms of aggression of which the stronger members are capable. Law should keep watch over the satisfaction of individual desire, not promote it blindly, and should equalize individuals when the desires of the strong threaten the cohesiveness of the collective. Courts of law, like the Rule of Law itself, must engage in this vital moral task. Courts should do as Tribe instructs: consider both the history of the distribution of power between the litigants before them and the distributive impact of the decisions they render. ${ }^{151}$ Desire and the objects of desire must on occa-

181 Thus, Tribe argues:

Professor Easterbrook tells us that what we need to ask is what effect the alternative rules will have on the future behavior of individuals; but he does not bother to inquire how those same alternatives will affect the future distribution of power and wealth among those individuals, nor does he care to know how the parties actually before the court initially arrived at their unequal positions. This disregard of the distributional dimension of any given problem is characteristic of the entire law-and-economics school of thought, which assumes a world in which no one is economically 
sion be renounced and not, as Easterbrook insists, merely regulated for the sake of ever greater satisfaction.

\section{B. The Critical and Feminist Alternative: Love, Empathy, and the Oceanic Feeling}

Unlike legal economists, critical and feminist legal scholars agree with Freud that individuals possess aggressive, antisocial inclinations and that those inclinations pose a problem of power. ${ }^{152}$ However, more and more feminist and critical scholars deny Freud's second claim: that individuals are incapable of empathic nurturing in the public sphere. ${ }^{153}$ According to these "communitarian" theorists, the origin of our capacity for public, empathic nurturing is a dimly remembered ${ }^{154}$ feeling of life-giving solidarity with the others in our world. Furthermore, it is this capacity for connectedness and the memory of oneness-not the capacity for obedience and the memory of helplessness-that lie at the heart of our social inclinations and disinclinations:

[W] are constituted as social beings by the desire to be recognized by others in an empowering, life-giving way. It is this fundamental experiential need that animates a baby's search for "eye-contact" with mother as well as the organizational efforts of adults who try to form into groups to vitalize their work-situations through the achievement of solidarity. While our actions are obviously also motivated by other factors (like the baby's need for food or the workers' need for

coerced and in which individuals who do not "buy" things are said to be "unwilling," rather than unable, to do so.

Tribe, supra note 6, at 594-95 (footnotes omitted).

183 See, e.g., Dalton, An Essay in the Deconstruction of Contract Doctrine, 94 YAlE L.J. 997, 1005-09 (1985); Kennedy, Distributive and Paternalist Motives in Contract and Tort Law, with Special Reference to Compulsory Terms and Unequal Bargaining Power, 41 MD. L. REv. 563, 566-67 (1982) (arguing that social welfare is always determined by a struggle or competition among individuals and groups for a finite supply of desirable goods).

15s See, e.g., Gabel, The Phenomenology of Rights-Consciousness and the Pact of the Withdrawn Selves, 62 TEx. L. REv. 1563, 1563 (1984) (expressing the opinion that human beings are never "alienated entirely from one another"); Kennedy, supra note 152, at 563 (suggesting that "the basis of [the] paternalism [of the state] is empathy or love").

164 By "dimly remembered," I do not mean to attribute to the critical legal scholar a kind of Lamarckian view of development. See supra note 81. Indeed, the capacity for oneness is of the same character as a Freudian instinctual desire that is part of our constitution at the present time but has been repressed. See Gabel, supra note 153, at 1566-67 (arguing that people lose confidence that others are also motivated by a desire for community and so suppress such desires from their everyday interactions with others). 
safer working conditions), it is the desire to connect through this confirming or genuine reciprocity that gives to our actions their distinctive social energy, impelling us out toward the other even when, as in the case of schizophrenics, the likelihood of success seems very small. ${ }^{155}$

If the memory of oneness and the capacity for empathic connection, rather than the memory of helplessness and the capacity for obedience, are at the heart of our social interactions, then those interactions have a radically different emotional content and value than that envisioned by Freud. The helplessness that inspires the strategy of obedience in the Freudian scheme leaves a memory of fear, desperation, rage, and dependency. Rebellion over personal authority is a good feeling, and freedom from oppression is thus positively valued. Similarly, oppression-unsuccessful revolt-is a bad feeling, and hence negatively valued. The "oneness" described by the communitarian theorist, by contrast, is a good feeling that leaves a memory of contentment and unity. Thus it is the sense of community and connection, not liberty and freedom, that affectively feels good and normatively is good. ${ }^{166}$ And it is alienation-separateness from the other, or lack of connectedness-not oppression, that feels bad and normatively is bad. ${ }^{157}$ To the Freudian fear of domination by authority, the communitarian answers with her own fear of alienation from the other.

The communitarian conception of the origin of our social impulses and the nature of the social "good" entails a radically different solution to the problem of power than that offered by Freud. If, instead of helplessness, a remembered feeling of oneness grounds our social inclinations, then the solution to the problem of power lies in our capacity for overcoming our separation, not in "subsequent obedience" to authority. The social inclination will feel like an act of diluted love for the other, rather than like an act of obedience towards a hated but needed father. To the extent that law is part of the solution to the problem of power, the struggle that it mediates is one's attempt to build a bond with an equal who is at times loving and at times hostile, rather than one's compelled obedience to a father against whom one has rebelled and on whom one has relied. Thus, to the Freudian and liberal promise that law can bring artificial equality and therefore freedom from the tyranny of unequal power, the feminist and critical scholars answer with their own promise that law at its best can bring an empathic and loving

\footnotetext{
1ss Gabel, supra note 153 , at 1566-67.

156 See id. at 1567-69.

157 See id.
} 
community and, with that, a release from the anguish of alienation and separateness.

Thus, to the communitarian scholar, the central concern of law is not the tension created by our ambivalence between obedience and rebellion, but the tension between our present separateness and our remembered union with the world at large, particularly with the strangers in it. ${ }^{158}$ The promise and the problem of law are centered, respectively, on the individual's potential for embrace and withdrawal. We create our own world, including the degree of connectedness we feel with others. ${ }^{158}$ One of the ways in which we create our own world is through legal norms, which can in turn be understood only by reference to the schism between self and other. ${ }^{160}$ The potential that law holds out, when so conceived, is not the resolution of "vertical" tensions between child and parent, weak and strong, or state and individual, but the resolution of "horizontal" affective tensions between citizen and cocitizen-between self and other, egotism and altruism, individualism and communitarianism. ${ }^{161}$ The Rule of Law, as well as particular laws, contracts, or moral norms, becomes, potentially, not an impersonal imperative to which subsequent obedience is owed, but an opportunity for recasting the net: for redrawing, once again, the line between self and other, between separateness and unity. ${ }^{\mathbf{1 6 2}}$

Glare Dalton's description of contract law is representative of the view of law suggested by this depiction of the affective base of our legal personality. ${ }^{163}$ Dalton begins with a stark denial of Freud's insistence that in the mature individual the border between self and other, between subjective and objective, is well demarcated. ${ }^{\mathbf{1 6 4}}$ The border between the self and the world, Dalton argues, is constantly shifting because our feelings towards others are frequently ambivalent and

188 See Hutchinson \& Monahan, Law, Politics, and the Critical Legal Scholars: The Unfolding Drama of American Legal Thought, 36 STAN. L. REv. 199, 209 (1984) ("[C]ontemporary legal thought [i.e., liberalism], in all its different guises, reproduces rather than resolves the basic contradiction [between individualism and community.]").

160 Peter Gabel explains that the alienation we feel from one another refers "to a quality of . . . experience that exists inside of us" and that "we can sometimes make our own truth through a kind of "existential retranslation." " Gabel, supra note 153, at 1565.

160 See id. at 1569-71. Peter Gabel describes the law as a "kind of defense-mechanism," id. at 1569 , to which people look to justify the internal conflict between the desire for connection and the need to deny that desire. Id. at 1569-71.

161 Clare Dalton argues that the central questions of power and knowledge in the law "devolve from the split between self and other, subject and object." Dalton, supra note 152 , at 1000 .

${ }_{162}^{162}$ See id. at 1113-14; Gabel, supra note 153, at 1597-99.

105 See Dalton, supra note 152, at 999.

164 See id. at 1002. 
therefore unpredictable. Both the promise and the problem of law, including the law of contracts, arise from ambivalent feelings of both knowledge and ignorance of the other and fear and love for the other: ${ }^{165}$

The stories told by contract doctrine are preoccupied with what must be central issues in any human endeavor of our time and place. One set of questions concerns power: What separates me from others and connects me to them? What is the threat and the promise to me of other individuals? Can I enjoy the promise without succumbing to the threat? Am I able to create protective barriers that will not at the same time prevent me from sharing the pleasures of community? What is the role of the state in regulating my relations with others? The other set of questions concerns knowledge: How can I know what others see, what they intend? On what basis can I share my understanding of the world with others? Is there a reality separate from my grasp of it? Is communication possible? These central questions of power and knowledge devolve from the split between self and other, subject and object, which structures our experience of the world. ${ }^{108}$

By learning, through deconstructive analysis, the methods by which we disguise the divide between self and other, Dalton explains, we empower ourselves to redraw those lines that "structure our experience":

My story reveals the world of contract doctrine to be one in which a comparatively few mediating devices are constantly deployed to displace and defer the otherwise inevitable revelation that public cannot be separated from private, or form from substance, or objective manifestation from subjective intent. The pain of that revelation, and its value, lies in its message that we can neither know nor control the boundary between self and other.

... By presenting doctrine as a human effort at worldmaking, my story focuses fresh attention on those to whom we give the power to shape our world. . . . This kind of inquiry ... can help us see that the world portrayed by traditional doctrinal analysis is already not the world we live in, and is certainly not the only possible world for us to live

${ }^{188} I d$. at $999-1000$ (footnote omitted) (emphasis added). 
in. And in coming to that realization, we increase our chances of building our world anew. ${ }^{\mathbf{1 6 7}}$

If the central problem of law is not the relation of son to father, but of self to other, the solution to the problem of power lies not in our potential for subsequent obedience to the depersonalized authority of the Rule of Law, but in our capacity for empathic affection. ${ }^{188}$ The Rule of Law, and the break between son and father it facilitates, is not only or even primarily a victory over the tyranny of personal power. It is also an obstacle to the encouragement of intersubjective unity. The reification of rights ${ }^{\mathbf{1 6 9}}$ that the Rule of Law facilitates-championed by the liberal as the law's greatest triumph-at times increases rather than bridges the distance between us. ${ }^{170}$ It is not the Rule of Law, but empathy, that can unite the self with stranger, co-contractor, and even colitigant. It can unite majority with minority, community with individual, and strangers with neighbors and friends. ${ }^{171}$ The goal of law then should be to encourage such empathic intersubjectivity. ${ }^{172}$ The obstacle

167 Id. at 1113-14.

168 Peter Gabel notes that social movements that are successful in the "universal sense" are able to "use a rights-strategy ... with the ultimate aim of creating an experience of public community that [can] dissolve people's belief in and obedience to the State itself." Gabel, supra note 153, at 1596. It is only then that people appreciate the role of law in perpetuating the schism between the self and others. See id. at 159697.

168 In Marxist thinking, to reify a concept such as a right is to invest it with qualities over and above those of the particular human beings who created or use it. It is as if the right had a life of its own. It exists independently of the particular social setting from which it came and continues regardless of the conscious choices of the people in a later setting.

Sparer, Fundamental Human Rights, Legal Entitlements, and the Social Struggle: A Friendly Critique of the Critical Legal Studies Movement, 36 STAN. L. REv. 509, 526 (1984). An example of the reification of rights is the characterization of certain rights as "inalienable" or "universal." Id. "[The liberal] language of rights attempts to describe how people can defend the interests they have by virtue of their humanity against efforts by others to suppress those interests or to live indifferent to the suffering caused by failing to recognize the interests of others." Tushnet, An Essay on Rights, 62 TEx. L. REV. 1363, 1382 (1984).

170 See Kennedy, supra note 152, at 648 (The liberal belief in "freedom of contract" has prevented reference to paternalism as a viable explanation for the rules of contractual agreements and the existence of certain compulsory terms in contract law, with the result that the intersubjective solidarity that could be fostered between the paternalistic intervenor and the subject of the intervention is precluded.); Tushnet, supra note 169, at 1382-83 (To the critical scholar, the characterization of human interaction as instances of the exercise of abstract rights masks its real and experiential nature.).

${ }^{171}$ See Kennedy, supra note $\cdot 152$, at 649 (arguing that middle-class decisionmakers should, before abandoning paternalism, "break! ] down the barriers of segregation by knowing others, rather than just making rules for them").

172 Duncan Kennedy explains:

The basis of paternalism is intersubjective unity of the actor with the 
to the extension of empathy to the public sphere is not the Freudian danger of the tyranny of love-its possessiveness or exclusivity-it is the danger of the ignorance of love, ${ }^{173}$ itself a function of the gulf between self and other. ${ }^{174}$ Law, at its best, can and should help us to bridge the gulf.

\section{Freud's Response: The Oceanic Feeling and the Need for the Totem}

Although Freud did not speak directly to this alternative explanation for the Rule of Law, he did consider-and reject-its psychological underpinnings. Freud opens Civilization and Its Discontents with a

other; it is identification and intimate knowledge. But the most fundamental characteristic of social life in our form of capitalism is social pluralism, which is a euphemism for social segregation and consequent ignorance and fear of one group for another. In the context of segregation, ignorance and fear, the risks of paternalist intervention are multiplied far beyond what they are in private life.

Id. at 647 .

173 "Ignorance of love" can be traced to the suppression of the desire for love in response to the fear of love's loss. Cf. Gabel, supra note 153, at 1568 ("As a result of . . . early experiences of the distancing other, we internalize a memory of loss with which desire itself becomes permanently associated."). Thus, in addition to external constraints, the creative potential of intersubjective unity "derives ... from the incapacity of intersubjective desire to transcend the circular and self-reproducing constraint it has imposed upon itself in response to the fear of loss." Id. at 1569.

174 Thus, Peter Gabel warns:

To the degree that the movement is successful . . . it can use a rights-strategy as part of its effort to leverage itself into public space with the ultimate aim of creating an experience of public community that could dissolve people's belief in and obedience to the State itself-it is only then that the judge can appear as a man in a tunic and "the law" can appear as something like his speech-impediment. But to the degree that the State is successful in using its rights strategy to tempt the movement to substitute rights-consciousness for its own critical self-understanding, the movement's members will gradually find themselves losing each other in their legal reflection and becoming attached to this reflection as the medium through which they recognize one another ....

. . [T] The movement's ... ["legal strategy"] has got to subsume the goal of expanding its rights within a more general effort to expand its evocative appeal. . . . [T] symbolic authority that are used by others to generate the "belief" through which alienation becomes the law, the more likely it is that we can inspire others to inspire us that we know what we're talking about-that we can, you know, be ourselves, make contact, have a good time, "take control of the means of production," and generally come out from behind the fabric of appearances through which we make each other hostage to the illusion that it is distance rather than a good heart turned outward that the law in us requires.

Gabel, supra note 153, at 1596-99 (emphasis added). 
friend's description of his own intensely pleasurable feelings of "oceanic oneness" with the world. The friend believed that it is this feeling of "oceanic oneness," not feelings of dependency, helplessness, and obedience, that gives rise to religious feeling and hence totemic experience:

[The "true source of religious sentiments"], [my friend] says, consists in a peculiar feeling, which he himself is never without, . . . which . . . is present in millions of people. It is a feeling which he would like to call a sensation of 'eternity,' a feeling as of something limitless, unbounded-as it were, 'oceanic.' This feeling, he adds, is a purely subjective fact, not an article of faith; . . . it is the source of the religious energy which is seized upon by the various Churches and religious systems, directed by them into particular channels, and doubtless also exhausted by them. One may, he thinks, rightly call oneself religious on the ground of this oceanic feeling alone, even if one rejects every belief and every illusion. ${ }^{175}$

Freud's rebuttal of this depiction of the origin of totemism begins with his confession of the absence of this feeling within himself:

I cannot discover this 'oceanic' feeling in myself. . . . [I]t is a feeling of an indissoluble bond, of being one with the external world as a whole. . . . From my own experience I could not convince myself of the primary nature of such a feeling. But this gives me no right to deny that it does in fact occur in other people. The only question is . . . whether it ought to be regarded as the fons et origo of the whole need for religion. ${ }^{\mathbf{1 7 6}}$

Freud concludes that the "oceanic feeling" should not be regarded as the explanation for religious need and offers a psychoanalytic explanation of the origin of the feeling. He notes first that the ideational content of this feeling-the claim of "oneness" or unity with the outside world-is totally at odds with the "fabric of our psychology,"177 which

178 S. Freud, Civilization, supra note 9, at 11.

176 Id. at 12.

177 The idea of men's receiving an intimation of their connection with the world around them through an immediate feeling which is from the outset directed to that purpose sounds so strange and fits in so badly with the fabric of our psychology that one is justified in attempting to discover a psycho-analytic-that is, a genetic-explanation of such a feeling. ... Pathology has made us acquainted with a great number of states in which the boundary lines between the ego and the external world become uncertain or in which they are actually drawn incorrectly. ... Thus even the 
asserts the existence of a well-demarcated boundary between the self and the world: "Normally, there is nothing of which we are more certain than the feeling of our self, of our own ego. This ego appears to us as something autonomous and unitary, marked off distinctly from everything else."178

The only nonpathological exception to this concrete and universal certainty of separation of self and other, Freud notes, is romantic love. ${ }^{178}$ Those who achieve a more inclusive "universal love" can do so only by radically altering the nature of love itself. Instead of valuing the state of being loved, as most people do, those who love all of humanity value the state of loving. ${ }^{180}$ This indifference to reciprocity is at odds with the "oceanic feeling," because it precludes total connection between self and others. In Freud's view, universal love is an escape from real love; it serves as a protection against the potential injury of merging the self with another and the possibility of loss. The nature of "universal love" disproves, rather than supports, the notion of any "oceanic" union of more than two individuals. Thus, Freud denies, as unambiguously as the emerging feminist and critical scholars affirm, that there exists a constantly shifting line, either phenomenologically or in the law, between the limits of our self and the limits of our world. How, then, does Freud account for the feeling of an "oceanic oneness" with the world? $\mathrm{He}$ attributes the feeling to the memory of an

feeling of our own ego is subject to disturbances and the boundaries of the ego are not constant.

Id. at 12-13.

${ }^{178} I d$. (footnote omitted).

179 There is only one state-admittedly an unusual state, but not one that can be stigmatized as pathological-in which [the ego] does not [remain sharply distinct]. At the height of being in love the boundary between ego and object threatens to melt away. Against all the evidence of his senses, a man who is in love declares that ' $\mathrm{I}$ ' and 'you' are one, and is prepared to behave as if it were a fact.

Id. at 13 (footnote omitted).

${ }^{180}$ A small minority are enabled by their constitution to find happiness, in spite of everything, along the path of love. But far-reaching mental changes in the function of love are necessary before this can happen. These people make themselves independent of their object's acquiescence by displacing what they mainly value from being loved on to loving; they protect themselves against the loss of the object by directing their love, not to single objects but to all men alike; and they avoid the uncertainties and disappointments of genital love by turning away from its sexual aims and transforming the instinct into an impulse with an inhibited aim. What they bring about in themselves in this way is a state of evenly suspended, steadfast, affectionate feeling, which has little external resemblance any more to the stormy agitations of genital love, from which it is nevertheless derived.

Id. at 48-49. 
early, infantile stage of ego development in which the self indeed experiences the ego and the world as one: "An infant at the breast does not as yet distinguish his ego from the external world as the source of the sensations flowing in upon him."181 Only through learning to distinguish the elements of experience that remain permanently with him from those that elude him from time to time does the infant come to understand the division between the self and the world. ${ }^{182}$ Although eventually cast aside in preference to the "reality principle," this memory of oneness may persist as a present feeling even in the normal, mature individual:

[O]riginally the ego includes everything, later it separates off an external world from itself. Our present ego-feeling is, therefore, only a shrunken residue of a much more inclusive-indeed, an all-embracing-feeling which corresponded to a more intimate bond between the ego and the world about it. If we may assume that there are many people in whose mental life this primary ego-feeling has persisted to a greater or less degree, it would exist in them side by side with the narrower and more sharply demarcated ego-feeling of maturity .... In that case, the ideational contents appropriate to it would be precisely those of limitlessness and of a bond with the universe-the same ideas with which my friend elucidated the 'oceanic' feeling. ${ }^{188}$

Freud insists, however, that the "oceanic feeling" plays no role in the

181 Id. at 13-14.

182 As Freud explains the process:

[The infant] gradually learns to [distinguish his ego from the external world], in response to various promptings. He must be very strongly impressed by the fact that some sources of excitation, which he will later recognize as his own bodily organs, can provide him with sensations at any moment, whereas other sources evade him from time to time . . . and only reappear as a result of his screaming for help. In this way there is for the first time set over against the ego an 'object,' in the form of something which exists 'outside' and which is only forced to appear by a special action. A further incentive to a disengagement of the ego from the general mass of sensations - that is, to the recognition of an 'outside,' an external world-is provided by the frequent, manifold and unavoidable sensations of pain and unpleasure the removal and avoidance of which is enjoined by the pleasure principle .... One comes to learn a procedure by which, through a deliberate direction of one's sensory activities and through suitable muscular action, one can differentiate between what is internal-what belongs to the ego-and what is external-what' emanates from the outer world. In this way one makes the first step towards the introduction of the reality principle which is to dominate future development.

Id. at 14 (footnote omitted).

183 Id. at 15. 
development of our attitude toward totemic authority. It is the capacity for obedience and the memory of helplessness, not the capacity for oneness and the memory of connectedness, that underlie the totemic impulse. ${ }^{184}$

Of course, Freud recognized that people come together in groups and communities both to achieve specific goals and simply to live in common. ${ }^{185}$ Furthermore, Freud shared the communitarian view that the collective is defined by the emotional ties that hold the individuals in the group together. ${ }^{186} \mathrm{He}$ diverges from the communitarians with respect to the nature of the group's emotional ties. Freud admits that the members of groups are bound together by affection, but it is the love for their leader, not for one another, that gives them their solidarity. ${ }^{187}$ They all love the leader, and they are assured that the leader loves each one of them. ${ }^{188}$ The group members hold each other in high regard only because of this common point of identification. ${ }^{\mathbf{1 8 9}}$ Initially, the group member desires to be the sole object of the leader's love. When she realizes that this is impossible, she envies her rivals at first, but later feels solidarity with them when it becomes apparent that no single member of the group can or will possess the loved object entirely. ${ }^{180}$ Thus, the group is characterized in part by the equality of unsatisfied desire. ${ }^{191}$ Freud's initial assessment was that group interaction, far from meeting the communitarian ideal, is individualistic, un-

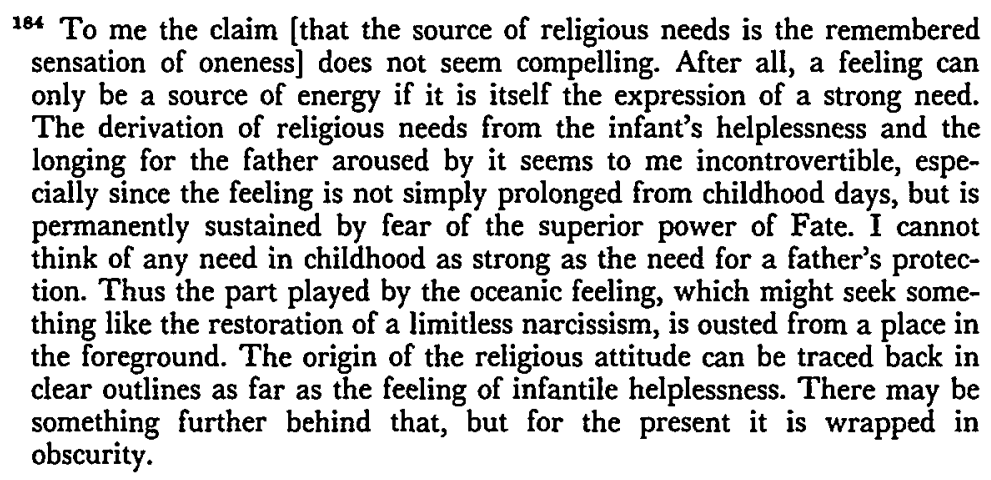

Id. at 19. For a response to Freud's analysis of the oceanic feeling by a feminist psychologist, see C. Gilligan, In a Different Voice 45-48 (1982).

185 See S. Freud, Group PsYchology, supra note 9.

${ }_{188}$ See id. at 23-24.

187 See id. at 26-27. A "leading idea" may serve the same libidinal purposes as a human leader. See id. at 27.

188 See id. at 26.

189 See id. at 28-29.

100 See id. at 52.

${ }^{101}$ See $i d$. ("If one cannot be the favourite oneself, at all events nobody else shall be the favourite."). 
generous, and based on a rechanneling of the group members' initial hostility towards one another. ${ }^{192}$ Upon closer examination, it became apparent to Freud that the egalitarian group, which is built on hostility towards others and love of the one, is none other than the father horde reconstituted. ${ }^{193}$ Further, it was clear that, like the brothers before the deed, "the group still wishes to be governed by unrestricted force; it has an extreme passion for authority . . . [and] a thirst for obedience."194

It is the capacity for obedience grounded in a dim memory of helplessness, not a smothered capacity for public love grounded in a dim memory of oceanic oneness, that is manifested in such social constructs as religion, conscience, and the Rule of Law. The state that assumes the contrary and attempts to mandate an expansion of the individual's affective capacity is attempting the impossible. Freud's description of the result of such attempts, if accurate, severely undermines Dalton's, Kennedy's, and others' insistence that a rule of empathy, and not the Rule of Law, can solve the problem of power. States that mandate rather than merely permit communitarian love within their borders generally do so at great cost to those who are perceived by the community as outsiders. The result, Freud argues, is tyranny, barbarism, and worse:

It is always possible to bind together a considerable number of people in love, so long as there are other people left over to receive the manifestations of their aggressiveness. . . . In this respect the Jewish people, scattered everywhere, have rendered most useful services to the civilizations of the countries that have been their hosts; but unfortunately all the massacres of the Jews in the Middle Ages did not suffice to make that period more peaceful and secure for their Christian fellows. When once the Apostle Paul had posited universal love between men as the foundation of his Christian community, extreme intolerance on the part of Christendom towards those who remained outside it became the inevitable consequence. To the Romans, who had not founded their communal life as a State upon love, religious intolerance was something foreign, although with them religion was a con-

192 See id. at 29 ("TT]he mutual ties between the members of the group disappear, as a rule, at the same time as the tie with their leader.").

$18 \mathrm{~S}$ See id. at 55-57. The feelings of the group members toward the leader can of course be distinguished from the social make-up of the primal horde: there, "all of the sons knew that they were equally persecuted by the primal father and feared him equally." Id. at 57.

104 Id. at 59. 
cern of the State and the State was permeated by religion. Neither was it an unaccountable chance that the dream of a Germanic world-dominion called for anti-semitism as its complement; and it is intelligible that the attempt to establish a new, communist civilization in Russia should find its psychological support in the persecution of the bourgeois. One only wonders, with concern, what the Soviets will do after they have wiped out their bourgeois. ${ }^{195}$

\section{The Liberal Response: The Need for the Totem}

Liberal theorist Charles Fried asserts that the feminist and critical scholars' encouragement of public love as the solution to the problem of power raises the threat of tyranny, not the hope of intersubjective unity between self and other. To Fried, the protection of the atomistic individual against the threat of forced unity is one important function of legal rights in the liberal system. It is Fried's intuition that the Rule of Law and the rights it protects are essential to any moral solution to the problem of power.

Fried's fear of forced communitarian love comes through clearly in his response to critical legal scholar Roberto Unger: "The liberal vision, according to Unger, keeps these two domains [the private domain of love, sharing, sacrifice, and altruism and the public domain of commerce and formalism] rigidly apart with the rent soul of man commuting uneasily between the two."196 Unger finds that this split between the public and private self is part of the problem of liberalism; he thus argues that the two spheres should be united, and that sympathy should be extended into public life. ${ }^{197}$ In response, Fried not only denies the wisdom of merging public and private, but asserts further that compelled unity, even in the family, can be tyrannical:

The contrast is false through and through. Certainly it is true that relations within a family must be governed by an altruistic spirit, a spirit of common purpose, sharing and sacrifice. . . . Yet this proves nothing. For the sharing within a family is and must be voluntary. Where the sharing is mandated by a higher authority it becomes despotism. A despotism may be benign, even necessary, as where parents enforce a regime of forbearance between their young children. But

195 S. FreUd, Civilization, supra note 9, at 61-62.

108 C. Fried, Contract as Promise 90 (1981).

197 See R. Unger, KNOWLedge and Politics 59-62, 260-62 (1975). 
such parental enforcement becomes gradually less tolerable as children grow older. Enforced against late adolescents or adults it is pure tyranny. ${ }^{108}$

If the mandate of altruism is oppressive in private, family relationships, it is clearly an act of despotism to mandate altruism and deny the enforcement of rights between contracting parties. Respect for others and their rights is consistent with the liberal program; denial of rights based on forced love and community is anathema to liberalism and a step toward the institution of tyranny:

Nor in commercial relations is there any imperative that the contractual partners refuse to share. . . The disposition to view one another with kindness and forbearance is an affirmative good, which liberalism is in no way committed to deny. But, just as in the family, the enforcement of such a posture itself tends to tyranny. Parties enter into contractual relations with certain expectations; for the state to disappoint those expectations is on its part a form of tyranny and deception. ${ }^{189}$

To Fried, the Rule of Law and the rights it protects are essential to any moral solution to the problem of power. Like Tribe, however, Fried supports his argument by reference to imagery and intuition rather than natural or historical fact. The basis of his critique of Unger is a simple denial, based on emotion and intuition, of Unger's premises. Unlike Freud, Fried does not provide a description of the human personality to explain why we should fear a legal system that encourages public love of our neighbors. If we do not agree that a regime that encourages empathy, instead of obedience, will lead to a frightful tyranny, nothing Fried says will convince us otherwise.

Again, Freud's naturalistic argument against the communitarian critique is significantly stronger than Fried's liberal and intuitionistic one. Freud provides an account of our nature that justifies Fried's fears. If Freud is correct about the limit of our capacity for love, then we are naturally constituted such that we can learn to do no more than respect each other. If this is true, the state should encourage us to respect, not overcome, our separateness from others. If Freud is right about our nature, then legal liberals are right to resist the merger of the public and the private. If private love is the only love of which we are capable, then we should, as Fried argues, protect the "natural" divide

108 C. FrIEd, supra note 196, at 90 (emphasis added).

199 Id. at $90-91$. 
between the worlds of private love and public respect.

\section{Indeterminacy and Obedience: Understanding the Commands of the Totem}

Finally, the critical legal scholar's claim that authoritative texts are indeterminate ${ }^{200}$ renders Freud's solution to the problem of power-renunciatory obedience to authority-incoherent. Freud claims that the problem of power posed by the individual's antisocial desires can be resolved by obedient compliance with the mandates of law. If, however, the authoritative texts that the powerful-including the powerful judiciary-must obey are indeterminate, then individual compliance with impersonal commands is impossible. The powerful individual will inevitably act in a free, empowered, and nonrenunciatory manner. This is because the totemic text cannot be obeyed until it is understood, and it can be understood only through a free act of interpretation. ${ }^{201}$ If obedience to authority is a necessary precondition to moral action, and if the authority we obey is embodied in texts that are by their very nature indeterminate, then the powerful interpreter is incapable of the renunciatory obedience that morality and legality require. If there is nothing coherent and determinate that we can obey, then we cannot renounce our aggression. If we cannot do that, we cannot solve the problem of power.

\section{The Freudian Response: The Erotic Aim of Civilization}

Does textual indeterminacy render the powerful individual's obedience to authority impossible? Although Freud's answer is ambiguous, his description of our nature clarifies the threat posed by the deconstructionist's claim more vividly than does the liberal response. As explained above, civilization's own erotic drive propels it toward growth and increase, while the individual's instinctual aggression mandates destruction. ${ }^{202}$ The individual's antisocial, aggressive desires are thus in

${ }^{200}$ By using deconstructive technique to take a text apart, the critical scholar seeks to establish the contingent and contradictory nature of any accepted interpretation. See Carter, Constitutional Adjudication and the Indeterminate Text: A Preliminary Defense of an Imperfect Muddle, 94 YALE L.J. 821, 823 (1985). The interpreter does not discover an independent, objective meaning in the text, but rather "sees reflected [in it] her own prejudices and convictions." Hutchinson \& Monahan, The Rights Stuff: Roberto Unger and Beyond, 62 Tex. L. REv. 1477, 1504 (1984). Thus, "[c]hoosing between values is inescapable." Hutchinson \& Monahan, supra note 158, at 208.

201 The interpretation adopted is ultimately a function of the individual's place in the existing social hierarchy and will reflect her position of power. See Carter, supra note 200 , at 823 n.6.

202 See supra notes $131-40$ and accompanying text. 
constant tension with the biological, erotic destiny of civilization as a whole. ${ }^{203}$ The conflict is resolved, to the extent it can be, by the individual's constant renunciation of power through obedient compliance to authoritative text. If the powerful individual cannot renounce her aggressive instincts due to textual indeterminacy, then she cannot align her interests with those of civilization. If that compliance is impossible, as the deconstructionist claims, then the coherence of the social unit itself is impossible.

Even if the commands of the text are certain, Freud doubts that the individual can consistently achieve the act of renunciatory obedience required by the cultural imperatives of any particular historical group. The erotic drive of civilization is at war with the antisocial instinctual apparatus of the individual. The outcome is not predetermined; the individual's attempts at obedience and renunciation will not inevitably win out. Law and religion, the principal forms of Freud's "cultural superego," often proceed in ignorance of this central conflict. Thus, the content of the cultural command may be too difficult for the individual to adhere to either consistently or at all. Modern society may tell the citizen to love her neighbor and the judge to obey the Rule of Law, but it remains indifferent to the citizen's or the judge's ability to act according to these cultural commands. Often the commands of the superego stretch the individual's capacity for obedience to the breaking point:

In the severity of its command and prohibitions [the cultural superego] . . . does not trouble itself enough about the facts of the mental constitution of human beings. It issues a command and does not ask whether it is possible to obey it.

${ }^{203}[\mathrm{C}]$ ivilization is a process in the service of Eros, whose purpose is to combine single human individuals, and after that families, then races, peoples and nations, into one great unity, the unity of mankind. Why this has to happen, we do not know; the work of Eros is precisely this. These collections of men are to be libidinally bound to one another. Necessity alone, the advantages of work in common, will not hold them together. But man's natural aggressive instinct, the hostility of each against all and of all against each, opposes this programme of civilization. This aggressive instinct is the derivative and the main representative of the death instinct which we have found alongside of Eros and which shares world-dominion with it. And now, I think, the meaning of the evolution of civilization is no longer obscure to us. It must present the struggle between Eros and Death, between the instinct of life and the instinct of destruction, as it works itself out in the human species. This struggle is what all life essentially consists of, and the evolution of civilization may therefore be simply described as the struggle for life of the human species. And it is this battle of the giants that our nurse-maids try to appease with their lullaby about Heaven.

S. Freud, Civilization, supra note 9, at 69 (footnotes omitted). 
On the contrary, it assumes that a man's ego is psychologically capable of anything that is required of it, that his ego has unlimited mastery over his id. . . . The commandment [love thy neighbor] is impossible to fulfill . . . . Civilization pays no attention at all to this; it merely admonishes us that the harder it is to obey the precept the more meritorious it is to do so. ${ }^{204}$

But if the deconstructionist is right, the conflict between the powerful individual and civilization is far more serious than Freud realized. Freud recognized that the individual may lack the strength to obey the commands of the impersonal totem, but the critical legal scholar's indeterminacy critique asserts that obedience is impossible not because the individual is weak, but because the command is uncertain. If textual authority is inevitably indeterminate, the powerful individual can never, regardless of the command's content, achieve the renunciation commanded by the legal, moral, or religious superego: the superego's commands cannot be obeyed without first being interpreted, and interpretation is an act of unrestrained power. If Freud's account of the necessity of obedient renunciation is accurate, and if the deconstructionist is right to insist on the impossibility of such obedience, then the problem Freud identified, "how to get rid of the greatest hindrance to civilization-namely, the constitutional inclination of human beings to be aggressive towards one another"205_still needs to be resolved.

\section{The Liberal Response: The Nihilism of Indeterminacy}

Legal liberals have failed to deliver a satisfactory response to the deconstructionist critique because they have yet to articulate clearly the dangers posed by textual indeterminacy. Owen Fiss's influential liberal article Objectivity and Interpretation ${ }^{206}$ is representative. Fiss identifies two principal types of deconstructionists: those who believe that the text holds all meanings and those who believe that the text holds no meaning. ${ }^{207}$ To those who believe in the multiplicity of textual content, Fiss responds that "disciplining rules"208 "constrain the interpreter, thus

\footnotetext{
204 Id. at 90.

205 Id. at 89.

200 Fiss, supra note 5.

207 See id. at 762 . "Either brand of nihilism liberates the critic as meaningcreator." Id.

${ }^{208}$ Disciplining rules are

a set of procedural norms to discipline the interpreter: The judge must stand independent of the interests of the parties or even those of the body politic (the requirement of judicial independence); the judge must listen to
} 
transforming the interpretive process from a subjective to an objective one, and ... furnishing the standards by which the correctness of the interpretation can be judged." 209 Thus, even if the legal text is ambiguous, the disciplining rules are clear, objective, and absolute and prevent the lone judge from straying too far from the objective meaning of the authoritative text. But from what source do these rules derive their coercive power? Why is adjudication that is based on adherence to such rules any more authoritative than the raw will of the individual? Fiss's answer tracks Freud's: the interpretive community-in Freud's language, the "might of the community"-determines that the disciplining rules are to be obeyed and ultimately is behind the centralized coercive force embodied in those rules. ${ }^{210}$ The disciplining rules are authoritative because they are chosen, determined, and followed by every member of the interpretive community. Membership in the community requires adherence to the rules, and uniform and objective interpretation is assured by the intersubjective unity that will always exist within the judiciary: $:^{211}$

Judges do not belong to an interpretive community as a result of shared views about particular issues or interpretations, but belong by virtue of a commitment to uphold and advance the rule of law itself. . . . [I]n legal interpretation there is only one school and attendance is mandatory. All judges define themselves as members of this school and must do so in order to exercise the prerogatives of their office. Even if their personal commitment to the rule of law wavers, the rule continues to act on judges; even if the rule of law

grievances he might otherwise prefer not to hear (the concept of a nondiscretionary jurisdiction) and must listen to all who will be directly affected by his decision (the rules respecting parties); the judge must respond and assume personal responsibility for that decision (the tradition of the signed opinion); and the judge must justify his decision in terms that are universalizable (the neutral principles requirement).

Id. at 754 .

$209 \mathrm{Id}$. at 745.

210 Fiss argues that

[r]ules are not rules unless they are authoritative, and that authority can only be conferred by a community. Accordingly, the disciplining rules that govern an interpretive activity must be seen as defining or demarcating an interpretive community consisting of those who recognize the rules as authoritative. This means . . that the objective quality of interpretation is bounded, limited, or relative. It is bounded by the existence of a community that recognizes and adheres to the disciplining rules used by the interpreter and that is defined by its recognition of those rules.

Id. at 745 (footnote omitted).

${ }^{211}$ See id. at 750. 
fails to persuade, it can coerce..$^{212}$

Fiss fails to explain, however, just how judges are to obey the command of these disciplining rules. Institutional values are totemic authorities that demand renunciation and subsequent obedience just as the rules of substantive law do. And, like any rule of substantive law, the "objective" rules of adjudication cannot be applied until they have been interpreted in a free and empowered way. Consequently, Fiss's apparent refutation of the indeterminacy critique misses the principal thrust of the deconstructionist attack.

To the "nihilist" whose indeterminacy argument assumes that the constitutional text is devoid of meaning, Fiss answers with a cry of fear. The claim that the Constitution is without content is a grave attack against modern liberal jurisprudence, because the most fundamental tenet of the legal liberal is that moral rights and prescriptions, and all of the values that we as a society cherish, inform and are protected by that document. ${ }^{213}$ If this "deepest and darkest of all nihilisms"214 were to succeed,

[t]he great public text of modern America, the Constitution, would be drained of meaning. It would be debased. It would no longer be seen as embodying a public morality to be un-

212 Id. at 746-47. Judges must, then, obey the commands of the totem:

Legal texts are prescriptive. . . . [T]heir purpose is not to describe, but to prescribe. For example, the statement in the fourteenth amendment that "[n]o State shall ... deny to any person within its jurisdiction the equal protection of the laws" is not meant to depict what is happening, much less what has happened, but to prescribe what should happen. It embodies a value-equality-and I see adjudication as the process by which that value, among others, is given concrete meaning and expression.

Id. at 751 .

213 As Fiss explains:

My defense of adjudication as objective interpretation, however, assumes that the Constitution has some meaning-more specifically, that the text embodies the fundamental public values of our society. . . The idea of adjudication requires that there exist constitutional values to interpret, just as much as it requires that there be constraints on the interpretive process.

Lacking such a belief, adjudication is not possible, only power.

....

. . I believe it imperative to respond, in word and in deed, for this nihilism calls into question the very point of constitutional adjudication; it threatens our social existence and the nature of public life as we know it in America; and it demeans our lives. It is the deepest and darkest of all nihilisms. It must be combated and can be, though perhaps only by affirming the truth of that which is being denied-the idea that the Constitution embodies a public morality and that a public life founded on that morality can be rich and inspiring.

Id. at 762-63 (emphasis added).

214 Id. at 763. 
derstood and expressed through rational processes like adjudication; it would be reduced to a mere instrument of political organization-distributing political power and establishing the modes by which that power will be exercised. Public values would be defined only as those held by the current winners in the processes prescribed by the Constitution; beyond that there would be only individual morality, or even worse, individual interests. ${ }^{215}$

The Constitution must have meaning to it, and it must be capable of authoritative interpretation, Fiss tells us, because if it is not, we are entirely without moral guidance. ${ }^{216}$ Judges can obey the command of the totem because morally they must obey. If the powerful cannot obey-if they cannot engage in actual and ritualistic renunciation-the community will face the unrestrained, liberated power of individuals, which is something to fear, not something to celebrate. "Individual interests" and the "individual morality" they reflect are diametrically opposed to our "public morality" and "public life." The nihilist assumes textual vacuity and concludes that obedience is impossible; the liberal insists "that the Constitution embodies a public morality and that a public life founded on that morality can be rich and inspiring,"217 and concludes that obedience is possible.

Fiss does not offer a factual basis for his fears, and as a result they seem oddly unjustified and somewhat hysterical. First, Fiss does not explain why there is a conflict between our "individual morality" and our "public morality." Second, he does not explain why we should prefer public over individual morality. And third, Fiss does not explain why the indeterminacy of texts threatens the individual's ability to act in accord with the dictates of public morality and public life. Fiss passionately believes that our public life is threatened if powerful individuals are incapable of obeying objective imperatives, but he does not explain why.

Freud's description of the relationship of the individual to civilization, and the nature of morality entailed by that relationship, provides answers to all three questions and hence a justification of Fiss's nightmare vision. First, if Freud's description of our nature is accurate, then Fiss is right to fear the "individual morality" of each of us. The danger posed by the individual is the instinctual attraction to death and destruction. "Individual morality" is therefore a contradiction in terms.

216 Id.

210 See id. at 762-63.

217 Id. at 763. 
Second, if Freud's account of the erotic drive of civilization is correct, then Fiss is right to insist on the value of group cohesiveness. If civilization exhibits a "life-force" to which the individual is hostile, then group cohesiveness-even if the group is chauvinistic, nationalistic, sexist, barbaric, hysteric, or worse-is of greater moral value then the conflicting "individual moralities" of each of us.

Finally, if Freud's depiction of the relation of the individual to civilization is accurate, then Fiss's fear that textual indeterminacy threatens the collective life of the group is justified. Textual indeterminacy implies our incapacity for obedience and renunciation. In Freud's vision, the powerful individual's renunciation of antisocial desire through obedience to objective, imperative norms is not the unfortunate byproduct, but the engine-both the source and the mechanism-for the erotic, unifying, and moral work of civilization. The deconstructionist's suggestion that we cannot obey totemic authority is "nihilistic" if and only if the individual's capacity for obedient compliance with authoritative texts is a necessary precondition for moral action. If Freud's account of our nature is correct, then judicial adherence to the Rule of Law is morally required because it is in "the service of Eros" and manifests the life-force of the community. If such obedience is impossible, then the community will die.

\section{Conclusion: The Future of Legal Liberal Illusions}

\section{$A$ dragon lives forever, \\ But not so little boys, \\ Painted wings and giants' rings, \\ Make way for other toys. ${ }^{218}$}

In The Future of an Illusion, Freud argues that religious masters rely primarily on the force of expulsion, not persuasion, to convince their audience of the autonomy and morality of divine law: any inquiry into the foundation of belief is strictly forbidden. ${ }^{219}$ Such a prohibition inevitably fosters suspicion; "[a]fter all, a prohibition like this can only be for one reason-that society is very well aware of the insecurity of

218 L. Lipton \& P. Yarrow, Puff (the Magic Dragon), Pepamar Music (ASCAP).

219 When we ask on what their claim to be believed is founded, we are met with ... . [the answer that] it is forbidden to raise the question of their authentication at all. In former days anything so presumptuous was visited with the severest penalties, and even to-day society looks askance at any attempt to raise the question again.

S. Freud, supra note 13, at 26. 
the claim [religion] makes on behalf of its religious doctrines." ${ }^{220}$ When the threat of expulsion fails to convince, the religious masters insist that the audience should believe simply because the religious claim is absurd:

[T] he 'Credo quia absurdum' of the early Father of the Church . . . maintains that religious doctrines are outside the jurisdiction of reason-are above reason. Their truth must be felt inwardly, and they need not be comprehended. . . . [But as] an authoritative statement [this Credo] has no binding force. Am I to be obliged to believe every absurdity? And if not, why this one in particular?221

And finally, if absurdity does not convince, the audience is commanded to act as if the religious belief were true: "[T]he philosophy of "As if . . . asserts that our thought-activity includes a great number of hypotheses whose groundlessness and even absurdity we fully realize. They are called 'fictions,' but for a variety of practical reasons we have to behave 'as if' we believed in these fictions." 222

Although sensitive to the community's need for totemic authority, Freud ultimately rejects the demand of the religious authority for a rational obedient belief and invites the audience to join him. In a moment of uncharacteristic optimism, Freud argues that there are nontotemic solutions to the problem of civilization and that there is no need to follow the religious believer's childlike obsession with false tales:

I think the demand made by the 'As if' argument is one that only a philosopher could put forward. A man whose thinking is not influenced by the artifices of philosophy will never be able to accept it; in such a man's view, the admission that something is absurd or contrary to reason leaves no more to be said. It cannot be expected of him that precisely in treating his most important interests he shall forgo the guarantees he requires for all his ordinary activities. I am reminded of one of my children who was distinguished at an early age by a peculiarly marked matter-of-factness. When the children were being told a fairy story and were listening to it with rapt attention, he would come up and ask 'Is that a true story?' When he was told it was not, he would turn away with a look of disdain. We may expect that people will soon 
behave in the same way towards the fairy tales of religion, in spite of the advocacy of "As if." 223

Freud's treatment of the attempts of religious masters to shield their faith from inquiry is equally applicable to modern liberal defenses of the autonomy and morality of law. Like the religious masters, legal liberals resist attempts to ground their faith in the Rule of Law in human nature or human history. Instead, their audience is told to believe in the autonomy of law in spite of the historical absurdity of such a claim; to behave as if they believed in the law's necessary morality; and, finally, if still skeptical, to vacate the law schools.

The religious believer cannot embrace Freud's naturalistic account of religious belief and continue to believe. The claim that divine authority is transcendental-that God is not man's creation-must be abandoned if Freud's history of our authoritarian inclinations is accurate. Freud's parallel account of the origin of law, however, has different implications. Unlike religious masters, legal liberals could embrace a naturalistic explanation such as Freud's to justify their beliefs. Neither the autonomy nor the moral authority of the Rule of Law is dependent on the proposition that the Rule of Law is of truly inhuman or transcendental origin. Unlike divine authority, the authority of the Rule of Law depends only on a denial of an authorial claim by any particular person. Thus, legal liberals could embrace a naturalistic account of the reconstitutive origin of totemic authority and continue to insist that it binds us all. Naturalistic descriptions of the origin and function of obedience to totemic authority do not pose the same threat to the belief in Law that they pose to the belief in God.

Freud's explanation, of course, may not be the best naturalistic account of the morality or autonomy of law. ${ }^{224}$ Freud's descriptive as-

22s Id. at 29; cf. Gabel, supra note 153, at 1567 (suggesting that we adapt to our alienation to one another by assuming roles and behaving "as if" we feel connected to one another).

${ }^{224}$ Freud's account has been criticized for resting on "scanty evidence," as there is no proof of the existence of the primal horde he describes. See P. RoAzEN, supra note 9, at 154, 266. In Freud's defense, Paul Roazen suggests three factors that informed his allegiance to the story. First, Freud, unable to convince "himself of the strength of fantasies, . . . had to have a 'real' trauma, a 'real' murder of the primal father." Id. at 155. Second, like anthropologists of his era, Freud "translat[ed] "essence" into "origin," so that the statement "this is the essence of the situation" bec[ame] "this is how it began." " "Id. at 156 (quoting S. HyMan, The TANGLed BaNK 366 (1962)). Finally, Freud's historico-anthropological explanations must be read in the context of Freud's ongoing dispute with Jung. See id.

During his lifetime, Freud acknowledged that he was using what many considered to be outmoded anthropology. Specifically, he was criticized for overemphasizing the killing of the father as the "prototypical event" to the exclusion of the fratricides and filicides that also appear in myth and literature. P. RrEFF, supra note 9, at 195. Freud 
sumptions about our nature and history may well be false. They are certainly controversial: recent feminist, psychoanalytic, and anthropological scholarship throw considerable doubt on both the empirical and the historical assumptions of Freud's theory of law. We may not be any more inherently aggressive than we are inherently compassionate. Empathy and love, not obedience and renunciation, may indeed hold the key to moral action. Primitive, pre-legal life may have been (and in some parts of the globe, continues to be) far more peaceful than Freud believed. However, the falsity of Freud's historical claims does not entail the failure of his phenomenological, clinical, empirical, and naturalistic method. Independent of the truth or falsity of Freud's description of our nature, the power of his jurisprudence demonstrates that the moral authority of law can be coherently defended by reference to naturalistic, and therefore falsifiable, assumptions. Such an argument undoubtedly explodes the Rule of Law's "transcendental" and "categorical" claim to authority: it renders the Rule of Law's authority contingent on fact instead of faith. By doing so, however, it strengthens, not weakens, its claim on our imagination.

Modern legal liberals are not compelled to use arational methods to defend their commitments; they have nevertheless chosen that mode of argument. By choosing the path of faith and rejecting the path of reason, modern legal liberals unwittingly cast themselves and their critics in the respective roles of religious master and skeptic. As long as the liberals stick to this choice-as long as their belief in law lacks contingent grounding in nature and history-the future of their illusion is clear: the Rule of Law will fail to convince. Like religious skeptics, the critics of legal liberalism will not pledge their commitment to the morality of law because they have been told to. Nor will they endorse the law for its soothing effect if they find the law absurd. Liberalism's crit-

justified his use of the anthropology he chose, writing that "[i]t was my good right to select from ethnological data what would serve me for my analytic work." S. FREUD, supra note 27 , at 169 .

Feminist and psychoanalytic critics of Freud's primal horde narrative have focused on Freud's failure to provide analysis of the domination of women in the precivilized natural state, and his consequent portrayal of the male's resolution of the oedipal conflict as the prototype for both the historical beginning of civilization and the individual acquisition of conscience. While Freud implies from his male prototype that female development is both precivilized and morally stunted, feminist psychoanalysts and theorists argue that women's distinctive development entails simply a different, and not an "inferior," sense of morality and meaning of civility. See generally N. CHODorow, The RePRoduction of Mothering (1978); C. Gilligan, supra note 184; Chodorow, Gender, Relation and Difference in Psychoanalytic Perspective, in THE Future of Difference 3 (H. Eisenstein \& A. Jardine eds. 1985); Flax, MotherDaughter Relationships: Psychodynamics, Politics and Philosophy, in THE FuTURE OF DIFFERENCE, supra, at 20. 
ics, upon being told that the authority of the Rule of Law "must not be challenged," or that its virtue "needs no defense," or that questions of justification will be met with expulsion, cannot be expected to banish their spirit of scientific skepticism. If the modern advocate of the Rule of Law refuses to engage in historical or naturalistic inquiry because there is greater comfort to be had in fairy tales, the modern skeptic, like Freud's child, will "turn away with a look of disdain" upon learning that the story being told does not even purport to be a true one. 